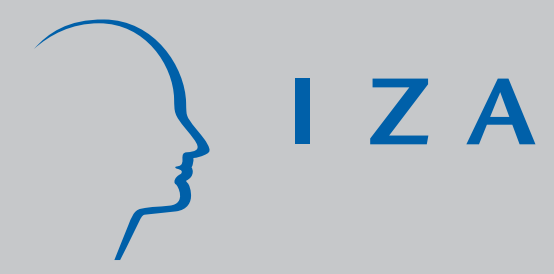

IZADP No. 1620

The Determinants of Firm Performance: Unions, Works Councils, and Employee Involvement/High Performance Work Practices

J ohn T. Addison

J une 2005 


\title{
The Determinants of Firm Performance: Unions, Works Councils, and Employee Involvement/High Performance Work Practices
}

\author{
John T. Addison \\ University of South Carolina, \\ Universidade de Coimbra and IZA Bonn
}

Discussion Paper No. 1620

June 2005

IZA
P.O. Box 7240
53072 Bonn
Germany

Phone: $+49-228-3894-0$

Fax: +49-228-3894-180

Email: iza@iza.org

Any opinions expressed here are those of the author(s) and not those of the institute. Research disseminated by IZA may include views on policy, but the institute itself takes no institutional policy positions.

The Institute for the Study of Labor (IZA) in Bonn is a local and virtual international research center and a place of communication between science, politics and business. IZA is an independent nonprofit company supported by Deutsche Post World Net. The center is associated with the University of Bonn and offers a stimulating research environment through its research networks, research support, and visitors and doctoral programs. IZA engages in (i) original and internationally competitive research in all fields of labor economics, (ii) development of policy concepts, and (iii) dissemination of research results and concepts to the interested public.

IZA Discussion Papers often represent preliminary work and are circulated to encourage discussion. Citation of such a paper should account for its provisional character. A revised version may be available directly from the author. 


\section{ABSTRACT \\ The Determinants of Firm Performance: Unions, Works Councils, and Employee Involvement/High Performance Work Practices}

Drawing on evidence from the United States and Germany, this paper offers a survey of the effects of worker representation (in unions and works councils) and innovative work practices on firm performance. The focus is on the growing links between these two historically separate literatures. The interaction between worker representation and high performance work practices provides a practical means of peering inside the black box of collective voice, even if there is as yet no well-determined hierarchy for productivity performance and certainly no blue-print for the future of unions.

JEL Classification: J51, J53, M54

Keywords: worker representation, employee involvement mechanisms, innovative work practices, training, firm/establishment performance

Corresponding author:

John T. Addison

Department of Economics

Moore School of Business

University of South Carolina

1705 College Street

Columbia, SC 29208

U.S.A.

Email: ecceaddi@moore.sc.edu 
"Their work [Freeman and Lazear, 1995] provides a theoretical basis for the presence and role of works councils but it could easily be applied to high performance workplace practices." (Black and Lynch, 2000, p. 8)

"German business would have had to invent codetermination if it had not been legislated.” (Remark attributed to Berthold Beitz, Managing Director, Fried. Krupp)

\section{INTRODUCTION}

In this paper we examine the associations between worker representation (i.e. in unions and works councils), employee involvement/innovative work practices, and various indicators of firm performance. ${ }^{1}$ The two themes of workplace representation and innovative workplace practices have historically been analyzed separately, although in recent years they have shown more overlap. There are a number of reasons for this historical apartheid. First, the (linking) theme of collective voice was first applied to unions, where it shared equal billing with unionism's monopoly face. ${ }^{2}$ Second, employee involvement has tended to be seen as management-led and thus as a human resource management technique emphasizing high-commitment employment practices. (At the price of some imprecision, we will equate innovative work practices with high performance work practices and use both interchangeably with employee involvement.) Third, and coinciding with the decline in unionism and growth in human relations practices, there has been the suggestion that the unions and employee involvement are alternatives. $^{3}$

On the other hand, several other forces have encouraged a more integrationist approach. First, developments in the collective voice model have emphasized cooperation 
and the possibility that institutional innovation might allow a decoupling of distribution from production and workplace issues. Second, the reduced bargaining power of unions might have produced the same result and elevated the pro-productive aspects of unionism subsumed under collective voice. The bottom line is that although most analyses of worker representation and employee involvement/high performance work practices have been conducted in isolation - while sometimes including the other as a control - research is beginning to consider their interaction.

In the present treatment, we will consider developments in the United States and Germany, only noting the British literature in qualification and en passant. The U.S. experience is of interest because it provides one of the least positive assessments of union impact while yet offering some early evidence of there being a mutually supportive relationship between union presence and employee involvement. The German experience is of interest because workplace representation occurs through the mechanism of the works council rather than the union. Historically, the works council has been viewed as the exemplar of collective voice because of its array of information, consultation, and participation/codetermination rights. Latterly, with the recognition of the bargaining problem, the German institution has become ever more closely identified with the expression of pro-productive voice by reason of its 'peace obligation' and the dual system of industrial relations within which it is embedded. That said, there has been comparatively little analysis of the interaction of workplace representation with more direct employee involvement mechanisms, although analysis of the training function might provide a promising bridge. 
The plan of the paper is as follows. To set the scene for our discussion of the empirical evidence, we first offer some theoretical conjectures on the efficiency properties of worker representation and employee involvement mechanisms. We next discuss for the United States the impact on firm performance of unions, employee involvement/high performance work practices, and their interaction. We follow this with a broadly parallel analysis for Germany, now with works councils substituting for the union institution. An interpretative section concludes.

\section{THEORETICAL CONJECTURES}

The arguments favouring unionism, works councils, and employee involvement/high performance work practices (EI/HPWP) are closely linked. Thus, the principal works council model is unambiguously an extension of the collective voice model, first advanced to make the case for unionism; the scope for EI/HPWP to improve performance rests on many of the same arguments used in the voice model; and the innovative work practices identified in the EI/HPWP literature may pierce the veil of the collective voice model which is opaque on mechanisms.

The collective voice model advanced by Freeman and Medoff (1984) is properly represented as a union voice-institutional response model. While arguing that voice is synonymous with (autonomous) unions, the authors are also concerned to make the point that voice cannot succeed without an appropriate response from management (and then from unions in response to any changes proposed by management). Freeman and Medoff (1984, p 165) write: "Some managements will adjust to the union and turn unionism into 
a positive force at the workplace; others will not. Over the long run, those that respond positively will prosper while those that do not will suffer in the market place.”

The centrepiece of collective voice is the union role in providing information. The labour market context is important here: it is characterized by continuity rather than spot market contracting because of on-the-job skills specific to the firm and the costs attaching to worker mobility and labour turnover. Given the information problem in such complex and multidimensional continuity markets, there are two basic mechanisms to elicit information on worker preferences or discontent. Quit behaviour can provide such information either inferentially or directly (via exit interviews). However, the collective voice model contends that such information is likely to suffer from selection biases, from problems of motivating the worker to disclose information when there is no benefit from doing so (and the certainty of some positive cost), and finally from the sheer cost of the process of trial and error in determining the efficacy of contract innovations.

The other mechanism is voice. Collective voice through the agency of a union may outperform individual voice for several reasons. One reason is that non-rival consumption of shared working conditions (e.g., safety conditions, line speeds, and grievance procedures) and common workplace rules create a public goods problem of preference revelation. Without some collective form of organization, there will be too little incentive for the individual to reveal his or her preferences since the actions of others may produce the public good at no cost to that individual. Unions collect information about the preferences of all workers and 'aggregate' them to determine the social demand for such public goods. Substituting average preferences for marginal preferences and arbitraging of worker preferences may be efficient in such circumstances. 
Unions can determine the social demand for such goods, thereby enabling firms to choose a more efficient mix of personnel policies.

A second public goods dimension of the workplace stems from the nature of the input of effort. Without some form of collective organization, so this argument runs, the individual's incentive to take into account the effects of his actions on others may be too small, just as with preference revelation. This problem will only arise where there are significant complementarities in worker effort inputs, so that output may depend on the lowest level of input by any one worker. In short, collective organization may potentially increase output through a joint determination of effort inputs and perhaps more so through increased cooperation between workers in continuity labour markets. ${ }^{4}$

The expression of collective voice is expected to reduce exit behaviour: quits, absenteeism, malingering, and even "quiet sabotage.” The reduction in quits in particular is expected to lower hiring and training costs and increase firm-specific investments in human capital. Apart from training effects, lower quits (inter al.) should also occasion less disruption in the functioning of work groups. Reduced exit behaviour is the most tangible source of potential efficiency gain (to the parties) in the model.

The other main aspect of collective voice is governance. In the context of the continuity relation, governance refers to the policing or monitoring of incomplete employment contracts. Governance will involve the use of grievance and arbitration procedures and other mechanisms to mitigate problems stemming from the authority relation. Such arrangements should help improve the flow of information between the two sides. The difficulty is that these specialized procedural arrangements are not unique to union settings, so that the argument presumably must be that unions make it easier (i.e. 
less costly) to negotiate and administer these arrangements. Unions may then facilitate long-term efficient contracting. A union specializing in information about the contract and in the representation of workers can prevent employers from engaging in opportunistic behaviour. Workers may withhold effort and cooperation when the employer cannot credibly commit to take their interests into account. Fearing dismissal, workers may be unwilling to invest in firm-specific skills or disclose information facilitating pro-productive innovations at the workplace. ${ }^{5}$ The formation of a union and the introduction of a system of industrial jurisprudence is one way of protecting employees' interests. In this way, unions may generate worker cooperation, including the introduction of efficiency-enhancing work practices. In other words, if the reputation effects mechanism is weak, there is scope for unionism to be pro-productive.

If we assume that there is a commitment problem in regular markets, an interesting side issue is whether the divorce of ownership and control in the modern corporation could make self-enforcing contracts more feasible. More feasible in the sense that management might be less interested in reneging on an implicit contract in the interest of short-term profit maximization than the owner principal; and conversely where the interests of managers and shareholders are more closely aligned by, say, profitsharing schemes for managers. In this case much might hinge on whether unions and selfenforcing contracts are substitutes or complements in establishing workplace cooperation. If they are substitutes, any positive effect of unions on performance will be stronger in firms with less severe agency problems. If they are complements, unions will be more effective in firms where agency stimulates self-enforcing contracts. This argument is of course based on a very narrow view of the agency problem in corporations and must be 
widened to incorporate rent-seeking behaviour by managers which may detract from trustful and cooperative industrial relations and may decrease the range of feasible selfenforcing contracts. Jirjahn (2003) has recently examined the relationships between unions (actually works councils) and self-enforcing contracts and also those between agency and trustful, cooperative industrial relations using information on management profit-sharing schemes. We shall report some of his findings when looking at the German evidence

While governance receives emphasis, there is virtually no discussion of bargaining power in the original collective voice model. But in contract theory models in which the union can make credible the employer's ex ante promises there must be some threat of credible punishment by the union (e.g., Malcomson, 1983). So it seems that the governance argument also depends on power: union monopoly power. Unfortunately, such power generally involves a hold-up problem, with unions taxing the returns on tangible and intangible capital.

The standard collective voice model treats the exertion of bargaining power and the expression of voice as distinct and offsetting facets of unionism (hence the reference to the "two faces" of unionism in Freeman and Medoff, 1984, p 5). Recognition of bargaining power is integral to the main theoretical justification for works councils in a model offered by one of the architects of collective voice. Thus, Freeman and Lazear (1995) argue that participation/codetermination will be underprovided by the market because institutions that give power to workers will affect the distribution as well as the size of the surplus. The ideas behind collective voice are fleshed out and set in a 
continuum bounded by information provision at one end and by participation or codetermination at the other.

Freeman and Lazear argue that the joint surplus of the enterprise will increase as one moves cumulatively from information exchange through consultation to participation. Among other things, information rights can help verify management claims as to the state of nature, rendering them credible to the workforce and avoiding costly disputes - even precipitating the failure of the enterprise. Consultation for its part allows new solutions to production and other problems by reason of the non-overlapping information sets of the two sides and the creativity of discussion. Finally, participation or codetermination rights increase the joint surplus by providing workers with more job security and encouraging them to take a longer-run view of the firm and its prospects.

However, Freeman and Lazear recognize that, unless constrained, these rights will give rise to a bargaining problem. Specifically, they argue that the workers' share in the joint surplus grows with the surplus while that of capital declines both relatively and absolutely. The workers' share rises because knowledge and involvement are power, so that the very factors that cause the surplus to rise also cause profitability to fall, with the result that workers will demand too much power/involvement because their share will continue to rise after the joint surplus has peaked. Symmetrically, employers will either oppose works councils or vest them with too little power because profits decline even as the surplus is increasing.

Some means of third-party regulation limiting bargaining power has to be found if the societal benefits of worker voice are to be realized. Here, Freeman and Lazear see the German institution as attractive in two respects. First, the German works council cannot 
strike. Second, neither can it formally engage in bargaining over wages and other conditions of employment unless expressly authorized to do so under the relevant industry-level or regional collective bargaining agreement. In this respect, the authors speak of a potential "decoupling" of the factors that determine the size of the surplus from those that determine its distribution. Left open is whether or not there is a sufficient decoupling in practice. Thus, even if the works council is an exemplary collective voice institution, theory does not provide an unambiguous answer as to its consequences for efficiency.

Finally, the starting point of the EI/HPWP model is the notion that "workplace innovations change the production function in such a way as to increase the productivity of a firm's inputs, in particular labour” (Cappelli and Neumark, 2001, p 739). The basic premise is by now familiar: workers have important private information and valuable insights into how to improve their jobs. There is therefore scope for beneficial trades once workers are trained and presented with better opportunities to exercise their skills through job redesign, decreased supervision, and involvement in decision making, and motivated to contribute through productivity bonuses (Handel and Levine, 2004, p 2). Recognition of these potentialities marks a shift in management philosophy from the status quo ante of traditional work systems and labor-management relations, even if there is considerable variation in how the new practices have been adopted in practice (for one taxonomy, see Godard, 2004).

EI/HPWPs 'work' by encouraging workers to work harder and smarter, and by inducing structural changes that improve performance. The idea that workers will work harder is based on their enjoying work more when the job is interesting and where it 
provides feedback and rewards (i.e. job enrichment). The second element more clearly reflects the distinct input of the worker in efficient job (re)design, not least when there are complementarities in production. As noted by Ichniowski, Kochan, Levine, Olsen, and Strauss (1996, pp 301-302), the final element reflects such factors as cross training and flexible job assignment, which can reduce the cost of absenteeism; decentralized decision making to self-managed teams, permitting a reduction in line management while benefiting communication; and training in problem solving and computer skills, which can increase the benefits of new information technologies. In other words, innovative work practices beget other changes that improve productivity independent of their effects on motivation.

The suggestion is that the various strands of employee involvement are interdependent and mutually reinforcing, Edgeworth complementarities. This is the notion of 'bundling,' namely, the idea that innovative high performance work practices are more effective when combined with supporting management practices (e.g., Milgrom and Roberts, 1995). As suggested earlier, compensation schemes such as profit sharing can incentivize employee involvement, and information disclosure and training can improve worker decisions at the same time as job security encourages them to take a long-run view of the firm and make suggestions. Another example is the potential synergies between job rotation, self managed teams, and pay-for-skill plans. However, this should not be taken to imply that the theory provides unambiguous guidance on either the identification or measurement of the bundles.

One other point needs to be made. Although many of these arguments are consonant with the voice model, the conjunction of the growth in EI/HPWP and the 
decline in unionism at least raises the possibility that the two may be substitutes, either by design or by effect (i.e., by enhancing worker satisfaction they may reduce the demand for unionism). This is not without consequence for the empirical work reviewed below in which the maintained hypothesis is often that the two institutions are complementary.

In sum, there are theoretical grounds for supposing that both collective voice and EI/HPWP can improve the productivity of the workplace. Some observers profess to see little difference in the arguments for workplace representation and EI/HPWP when the industrial relations system offers some means of some means of decoupling production from distribution issues. Others might still argue that traditional workplace representation through unions is important to the success of innovative work practices - by, say, providing greater assurance that a serious hearing will be given to employees' suggestions, or by virtue of union access to higher levels of management - or, backhandedly, that such practices offer a bigger payoff in union regimes with the elimination of restrictive practices, reminding us that in all such cases the monopoly face of unions has to be taken into account. Study of the effect of workplace representation on firm performance would seem to be quite closely bound up with the EI/HRWP issue. Moreover, comparisons between the United States and Germany might prove especially instructive.

\section{U.S. EVIDENCE}

We next review U.S. findings on the determinants of firm performance, first distinguishing between union and employee involvement effects and then addressing the comparatively few treatments that have attempted to integrate the two mechanisms. 


\section{Union Effects on Firm Performance}

The starting point for all analyses of union effects on firm performance must be Brown and Medoff's (1978) pioneering production function study of U.S. manufacturing, using aggregate two-digit industry data cross classified by state groups for 1972 . Using an augmented Cobb-Douglas production function, Brown and Medoff estimate

$$
\ln (Y / L) \approx \ln A+\alpha \ln (K / L)+(1-\alpha)(c-1) P
$$

where $Y$ is a value-added measure of output, $L$ is total labour (comprising union labour $L_{u}$ and nonunion labour $\left.L_{n}\right), A$ is a constant of proportionality, $K$ is capital, $\alpha$ and (1- $\left.\alpha\right)$ are the output elasticities of $K$ and $L, c$ indexes productivity differences between union and nonunion labour ( $c>1$ indicating union labour is the more productive, and conversely for $C<1$ ), and $P$ is union density, $L_{u} / L^{6}$

In this framework, the coefficient estimate for $P$ yields the logarithmic productivity differential of unionized establishments. Assuming this derives solely from labor inputs, dividing this coefficient by (1- $\alpha)$ gives the union labour productivity effect. Brown and Medoff estimate that the productivity of unionized establishments is between 25 and 27 percent higher than that of comparable nonunion plants, implying a union productivity effect of 35 to 36 percent. Interesting, as we shall see, some of the first production function studies for German works councils obtained similarly high estimates.

In the years since Brown and Medoff's study, evidence has steadily accumulated to the effect that average union effects in the United States are nowhere near as large as this. To start with, and abstracting from issues of restrictive functional form and limitations of value added as a measure of output, other similarly broadly-based studies 
have failed to confirm large effects. Perhaps the 'closest' study is by Hirsch (1991) who estimates a variant of the Brown-Medoff model using data for a sample of around 570 publicly quoted companies over the sample period 1968-80, matched to union data for 1977. Hirsch’s OLS value-added production function includes in addition to capital, labor, the stock of R\&D per employee, union density, variables measuring firm and industry growth, industry concentration, and import competition. He reports negative and statistically significant coefficients for union density (of around -17 percent). These estimates fall in absolute magnitude, the more detailed the industry dummies included: from -12.3 percent (2-digit level) through -8 percent (3-digit) to 3 percent (4-digit). Reestimating the production function for each of 19 industries yields some positive coefficient estimates for union density - examples include textiles and apparel, and fabricated metal products - but the majority of union effects remain negative. While conceding that union effects will likely vary considerably by industry and cannot be estimated precisely with existing techniques and data bases, Hirsch (1991, pp 104-105) nevertheless concludes that there is nothing to support the contention of large and statistically significant positive union productivity effects. Rather, union productivity effects are small on average and insufficient to offset the union wage differential.

We will return to the question of estimation technique (and the issues of omitted variables and union endogeneity) later in this discussion, but for completeness we should also note some findings from an earlier manufacturing industry study that are quite consistent with those of Hirsch. Using data from the Profit Impact of Market Strategy (PIMS) on 902 manufacturing businesses for 1970-80, Clark (1984) estimates similar value-added equations and finds small but well determined coefficient estimates for the 
union variable in the range -2 to -3 percent. On this occasion, however, the point estimates are not sensitive to inclusion of detailed controls. The bottom line is that, contrary to Brown and Medoff, average union productivity effects are small and as likely to be negative as positive. This interpretation is consistent with other pieces of information having to do with union effects on profitability (and employment).

Before turning to these other performance outcomes, it is important to emphasize again that we are speaking of average union effects and not results from individual industry and firm-specific studies that in principle can avoid many of the econometric and data problems inherent in more aggregative studies (e.g. in the measurement of output and in tackling input endogeneity problems). ${ }^{7}$ Such advantages are achieved at the price of a loss in generality, however, and so the goal must be to use the unique perspective of such studies to help inform more aggregative exercises.

Perhaps the most important indirect piece of evidence against large proproductive union effects of the magnitude suggested by Brown and Medoff's (1978) study is the U.S. evidence on profitability. Unlike the recent British evidence, every U.S. study points to reduced profitability in union settings. This result holds irrespective of the financial indicator used (price-cost margin, rate of return on sales or capital, or market valuation of the firm's assets/Tobin's q), unit of observation (aggregate industry, firm, or line of business), or methodology. On the basis of the 16 studies reviewed in Addison and Hirsch (1989), unions are associated with 10 to 15 percent lower profitability. More recent studies provide confirmation of this central tendency and, again inconsistent with British results, contain little indication of any material change in the magnitude of the union effect over time (Hirsch, 1991; Hirsch and Morgan, 1994). 
However, and again abstracting from issues of statistical inference, the profitability evidence is not without controversy because the union effect might just be a transfer and thus neutral from an efficiency perspective (assuming perfect capital markets). Indeed, this is the take of Freeman and Medoff (1984, p 186). Whatever the indications to the contrary in the earliest U.S. literature, however, subsequent research has indicated that unions do not capture a significant share of potential monopoly profits. For example, in his evaluation of profitability (two measures: Tobin's $q$ and the rate of return on capital) in 513 firms, 1968-80, Hirsch (1991) reports that although the four-firm industry concentration ratio is positively associated with profitability, the interaction between union density and concentration is both positive and statistically significant. In other words, the suggestion instead appears to be that union-nonunion differences in profitability are most substantial in highly competitive industries.

There are clearly other sources of union rents such as sales growth and protected markets. However, the source that has most exercised U.S. researchers is distinctly competitive: the current and future quasi rents - or normal returns - on firm investments. U.S. research consistently points to a strong negative association between unionism and investment in physical and innovation capital (Hirsch, 1991; Bronars and Deere, 1993; Bronars, Deere, and Tracy, 1994; Cavanaugh, 1998; Fallick and Hassett, 1999). The fullest analysis is by Hirsch (1991), who again presents pooled cross-section/time-series results for both types of investment in his sample of more than 500 firms. For capital investment he reports that the union firm with average coverage has annual capital investment that is 13 percent lower than its nonunion counterpart. The direct effect of unionism or the union tax on the returns to long-lived capital contributes a little under 
one-half of this effect. The other 7 percent is an indirect effect operating via the union impact on profitability, profits being an important determinant of capital investment. For R\&D expenditures, unionized companies invest some 15 percent less than do comparable nonunion firms. Well over three-quarters of this effect is now direct, resulting from the union tax. ${ }^{8}$ We should also note that Hirsch reports that union coverage is negatively associated with the ratio of advertising expenditures to sales. Furthermore, union coverage is also positively related to the propensity to patent, which should reduce the liability of the firm to hold up, ceteris paribus. That said, union coverage is unrelated to the ratio of debt to equity, higher values of which might be expected to lessen exposure to hold up (see, inter al., Baldwin, 1983).

The U.S. evidence on investments in tangible and intangible capital does not augur well for long-run productivity growth in unionized companies. However, this implication is not corroborated in the productivity growth literature, where the slower growth on unionized firms is due to a disproportionate presence of unionization in industries with slower growth. ${ }^{9}$ Hirsch (2004) contends that the implication of slowed growth in union companies is not inconsistent with this result because productivity growth equations typically control for both tangible and intangible capital. Vulgo: they address only the direct effects of unions, neglecting the important indirect effect operating through reduced investment. Accordingly, Hirsch directs our attention to the emerging employment growth literature (e.g. LaLonde, Marschke, and Troske, 1996; Dinardo and Lee, 2002). He interprets the evidence on slowed employment growth in unionized firms as the teleological outcome of their reduced investments in physical and intangible capital. That said, there is some lingering ambiguity in the notion of an 
employment maximand, as well as the potentially awkward result that unionized firms in the United States are apparently no more likely to fail than their nonunion counterparts. ${ }^{10}$

Summarizing, we see that on average union effects on productivity are small, that profitability is significantly reduced in union settings, and that investments in physical and intangible capital are also materially lower. The studies on which these findings are based attempt to deal with potential biases stemming from omitted variables and union endogeneity, but they not address mechanisms that might allow unionized establishments to do better than this, even outperform (some) nonunion plants.

\section{The Employee Involvement/High Performance Work Practice Literature}

As Cappelli and Neumark (2001, p 738) note, the literature on work organization and attempts to reform it is vast. Here we offer an eclectic review of the impact of innovative work practices on several measures of firm performance that always has an eye to unions, reflecting the conjecture that participatory systems might work better in union regimes (Levine and Tyson, 1990). We preface our summary of the empirical evidence with some cautionary remarks on methodology that arise in this literature and are additional to the classic problem of omitted variable bias encountered in the union literature.

One important preliminary issue is what constitutes high performance work practices. Although different researchers have used different measures (and terminology), there but is some broad agreement that employee involvement is central to the definition (e.g. Applebaum and Batt, 1994). More concretely, TQM programs, quality circles, functional flexibility, and teamwork are core elements of HPWP. Aiding such practices are individual and organizational supports (the terminology is that of Forth and Millward, 2004, p 100). Examples of the former are information disclosure, job rotation, and 
training, while the latter include job security guarantees, internal labour market structuring, and financial participation. Management practices that are difficult to fit into this mold, but are no less central, include benchmarking and computer usage. Despite this agreement, as Handel and Levine (2004, pp. 14-15) note, measurement problems arise because there is no theoretical guidance on which combination of practices might be more effective and no unambiguous way of measuring the bundles. As we shall see, researchers have used interaction effects, additive indices, factor analysis, and combinations supported by a priori reasoning. A potentially major complicating factor is that survey data may not go beyond identifying the presence of a practice, neglecting its reach, coverage and intensity.

Another important issue that needs to be raised at the outset is the diffusion of high performance work practices. Researchers typically do not have information on when a particular practice was initially introduced and typically do not have information on when it was discontinued. If researchers are observing a situation in cross section that is late in the diffusion of the practice in question, then any pro-productive effect will likely be biased downward. Also, there is a potentially serious loss of information arising from the failure to observe situations in which practices were discontinued. Even if the researcher has information on changes in practice (in either direction), and abstracting from measurement error, the panels are typically too short to accommodate learning effects. The bigger problem is of course that the number of changes in innovative practices in the typical panel is simply too small to take advantage of panel estimation techniques. 
The studies we next examine in detail are among the most recent U.S. empirical inquiries of workplace innovations. Since we focus on direct performance measures they do not include work on the relationship between EI/HPWP and earnings (for a review of which see Handel and Levine, 2004, Table 2). They constitute part of what Cappelli and Neumark (2001, p. 739) call the 'second wave' of research on organizational performance are very much in the spirit of the wider employee involvement/high performance work practice literature. Table 1 provides the bare bones.

(Table 1 near here)

Unionism is almost incidental in the first three studies in the table, and even when a union measure is included in the array of control variables its influence on the outcome indicator is scarcely documented. The leitmotiv of these studies is the attempt to make the best use of longitudinal and cross section data. In the case of the first row entry of Table 1, the goal is indeed methodological: Huselid and Becker (1997) provide a follow-up study of an earlier cross-section analysis by one of the authors (Huselid, 1995), now using panel data for 1993-96 to control for firm fixed effects while examining the sensitivity of the latter to measurement error. ${ }^{11}$

Huselid and Becker identify no less than 13 'human resource management practices’ and consider their impact on two measures of financial performance. Factor analysis is used to construct two factors measuring the extent of use each of the practices. The two factors are termed 'employee skills and organizational structures' and 'employee motivation,' suggesting that they may include constituent elements that others might not consider to be high performance practices (Godard, 2004, p 354). The control variables comprise capital intensity, employment, union coverage, the $R \& D$ sales ratio, and sales 
growth. The upshot of the authors' analysis is that factors having a statistically significant effect on financial performance in (three out of four) cross section(s) were no longer significant using a fixed effects specification. The story does not end here as Huselid and Becker report sizeable measurement error in the workplace practices. Based on independent estimates of the measurement error (Cronbach's alpha), they argue that the fixed effects estimates become closer to the cross section estimates and in particular that a one standard deviation increase in a unidimensional measure (being the sum of the two dimensions noted above) of high performance work systems increases the market valuation of the corporation by $\$ 15,000$ per worker. However, as noted by Cappelli and Neumark (2001, p 741), the problem of measurement error is exacerbated in a short panel of this nature because most firms would have had the work practices in question so that we would expect there to be little difference in their use over the two-year interval in question (the practices were observed in 1991 and again in 1993).

The advantage of the study in row 2 of the table is that in examining a single process - steel finishing - within an industry, the problem of output heterogeneity is presumably minimized. And in constructing a long time series, the beginning of which is likely marked by an absence of high performance work practices, the impact of those practices might be better discerned - subject to various caveats on the diffusion of the practices in question. In this study, Ichniowski, Shaw, and Prennushi (1997) identify 15 human resource management practices that cover incentive pay, recruitment and selection, teamwork, flexible job assignment, employment security, skills training, communication, and labor relations. As noted in the table, these are subsequently grouped into a hierarchy of four distinct human resource management systems. The delineation is 
on the basis of a priori reasoning, supported by several statistical procedures. The hallmark of this study is, then, a hypothesized complementarity of workplace practices. The workplace practices are accompanied by detailed controls (among the time-varying regressors included in the fixed effects specifications are age of line, start-up periods, the quality of steel input, and the introduction of new equipment). The dependent variable is product uptime.

It is reported that the more innovative human resource systems that significantly increase line uptime in cross section have similar effects when controlling for permanent unobserved line heterogeneity, unlike the study by Huselid and Becker in row 1 of the table. Consistent with that study, however, is the finding of complementarity in employment practices. Individual practices have little or no incremental effect on productivity. That is to say, when individual practices are added to regressions containing the HRM systems of practices, they have little additional effect on productivity; and in comparing these (OLS and fixed effects) regressions with ones containing only the individual practices, the typically well determined estimates for the latter (including in one specification a negative effect of unionism) effectively vanish with the addition of the system effects. Ichniowski, Shaw, and Prennushi (1997, p 311) conclude that "systems of HRM practices determine productivity ... while marginal changes in individual practices have little effect.” That said, there are some lingering ambiguities in the study stemming from the collinearity among practices, and no discussion of whether all practices in the round contributed independently of the other bundles (Godard, 2004, p $355)$. 
The study by Cappelli and Neumark (2001) in row 3 of the table uses information on working practices from a nationally representative sample of establishments based on two surveys (the National Employers Surveys for 1994 and 1997) with a high response rate. These establishments are matched to LRD data to obtain information on their performance, productive inputs, and other characteristics. Another distinguishing characteristic of the study is its use of multiple outcome indicators, the goal being to determine whether increases in productivity translate into improved performance by lowering unit costs.

To all intents and purposes, the high performance work practices are only observed at one point in time - strictly speaking the practices are observed in two years but five such practices are unique to the 1994 survey while six are asked of both surveys - but a long panel(s) is constructed by matching establishments in the cross section data to the 1977 LRD. Here the assumption is that the innovative work practices did not exist in 1997, so that the innovative practices in levels can be used in fixed effect specifications as all observations necessarily represent changes. The authors present results for two panels, 1977-93 and 1977-96, as well as for two cross sections, 1993 and 1996.

As in the row 1 and 2 studies, Cappelli and Neumark also look for synergies in innovative work practices. They first enter the practices individually and then in groupings suggested by design (e.g., teamwork training is designed to improve performance in teams and should be more productive with employee meetings and selfmanaged teams) or prior research. As shown in the table, the results are mixed, pointing to few synergies and much evidence of heterogeneity bias in cross section. In terms of the 
three outcome indicators, the main results are that high performance work practices raise labour costs per worker, that they may raise productivity (sales per employee), and that they have no effects on unit labour costs. The last result may mean that, at a pinch, productivity and labour costs may be offsetting.

The study in row 4 of the table is notable for being the first to do more than simply include a union variable in the control set. Cooke (1994) examines whether unionism positively or negatively influences the effectiveness of employee-participation programs and group-based incentives in his sample of Michigan manufacturing firms. Cooke's measure of performance is value added net of labour cost per employee. To calculate this magnitude he estimates three equations: value added per employee, wage rates, and labour cost/total cost. That is to say, he subtracts the estimated wage differential, adjusted by the labour cost share differential, from the estimated value added per employee differential to derive the performance measure.

His measure of employee involvement is a dummy variable indicating the presence or otherwise of team working, and his group incentives variable is another dichotomous variable capturing the presence or otherwise of either profit-sharing or gainsharing plans. These dichotomous variables are separately and jointly interacted with the union status of the firm; the omitted category being the compound 'nonunion/no gainsharing/no group incentive pay.' The other regressors include firm size, depreciable assets per employee (albeit only at the firm's 2-digit primary industry, so that the same capital intensity is assigned to union and nonunion workplaces alike), and proxies for the skill composition of the workforce, technology, and market power. 
Using the estimated differentials associated with each combination of employee involvement, group incentive pay, and union status, Cooke estimates their performance effects. The basic result is that unions elevate pay less than they increase productivity. Alone among the studies, Cooke reports that firm performance is 13 percent higher in unionized plants without either employee involvement or incentive pay than in comparable nonunion firms. The introduction of team working raises this differential to around 35 percent. By contrast, its introduction in the nonunion sector does not improve the innovating (nonunion) firm's net performance. In the absence of teamwork, group incentive pay has a much larger effect on efficiency in nonunion firms (+18.5 percent) than in union firms (+6.5 percent). In combination, the two measures also have a much bigger performance payoff in nonunion (+21 percent) than union (-0.7 percent) firms. While suggesting that the payoff to employee involvement and incentive pay may sharply differ in union and nonunion regimes, this study clearly paints a much rosier picture of union impact than the material reviewed earlier. Unfortunately, we are not told the statistical significance of the effects on performance. The cross section nature of the study, the deficiencies of the capital measure, and issues of representativeness are additional sources of concern.

The study in row 5 of the table attempts to deal with each concern. Black and Lynch (2001) estimate production functions for a large, nationally representative sample of manufacturing establishments. The authors fit augmented Cobb-Douglas production functions to both cross section and panel data for 1987-93, having much richer data than Cooke. ${ }^{12}$ The authors identify six high performance work systems (TQM, benchmarking, number of managerial levels, number of employees per supervisor, the proportion of 
workers in self-managed teams, and the $\{\log \}$ number of employees in training), two employee voice measures (unionization and the proportion of employees meeting regularly in groups), and two types of profit sharing (for management/ supervisors and production/clerical/technical). Panel techniques are used in an attempt to tackle a potential omitted variables problem due to unobserved establishment characteristics (but see below). Specifically, Black and Lynch use a two stage procedure that involves first estimating a fixed, time-invariant firm effect for each establishment using data for the time-varying factors - namely, capital, labour, and raw materials - and then regressing these fixed effects (or firm-level efficiency parameters) on all the time-invariant factors. ${ }^{13}$ The cross-sectional estimates indicate that, although most of the high performance work practices are positively associated with labour productivity, only benchmarking is statistically significant at conventional levels. Of the separate voice and profit sharing arguments the proportion of workers meeting regularly in groups - although not unionization - and nonmanagerial profit sharing are positively and significantly associated with productivity in most specifications. Contrary to the studies in the first two rows of Table 1, Black and Lynch report that there is no evidence of a synergistic bundling of the high performance work systems, although there is a positive and statistically significant association between unionization and nonmanagerial profit sharing. ${ }^{14}$ Finally, the results for the panel data second-step estimation are much the same as the cross-sectional results, although in the specification containing interaction terms the own effect of unionism becomes negative, much larger in absolute magnitude, and marginally statistically significant (even if this effect is more than counteracted by the positive interaction between unionism and nonmanagerial profit sharing). 
Black and Lynch use their estimates to show how unionized establishments that embrace what are termed "transformed" industrial relations practices can have higher productivity than nonunion plants. Specifically, a hypothetical union plant practicing benchmarking and total quality management, with 50 percent of its workers meeting on a regular basis, and operating profit sharing for its nonmanagerial employees is reported to have 13.5 percent higher labour productivity than a nonunion plant with none of these practices. By contrast, the corresponding differential for a high performance nonunion establishment is just 4.5 percent. In contrast to the row 4 study, however, if union and nonunion plants possess none of these workplace practices, the nonunion establishments have 10 percent higher labour productivity than their union counterparts. Note there is no attempt in this study to discover whether the workplace practices in question are positively related to average costs per worker (for evidence of which, see Cappelli and Neumark, 2001, in row 3).

Black and Lynch (2001, p 443) themselves note that, despite the use of panel methods, the regressors used in the second stage procedure refereed to earlier may still be correlated with unobserved time invariant plant level characteristics, thereby biasing the coefficient estimates on high performance workplace practices. One such variable is of course managerial quality. If more able managers are found in establishments that have greater recourse to such practices then the effects attributed to them may simply reflect good management. In the last row entry of Table 1, in their new study Black and Lynch (2000) present results from using a second wave of the dataset containing information on work practices and estimate a model in first differences, 1993-96 (as well in cross section for 1996). As can be seen from the table, compared with the row 5 study there is some 
redefinition of high performance work systems, including the use of a new variable 'reengineering.' Another change is that unionization is now interacted with four of the work practices, including the proportion of workers meeting regularly in groups.

The results differ somewhat from Black and Lynch (2001). Commenting here on just the fixed effects findings, we see that reengineering is the only work practice with a statistically significant pro-productive own effect. For its part, the own effect of unionization is poorly determined throughout, although when interacted with the worker meeting variable the effect is positive and statistically significant. The own effect of worker meetings is strongly negative. ${ }^{15}$

A final study not included in Table 1 nevertheless merits attention because it addresses the vexed issue of contingency in a union and high performance work practice context. The setting is the course of productivity at a single commercial aircraft manufacturer, 1974-91. During the sample period there were three strikes and one work to rule, one major production change, three (five) changes in top management (union presidents), and the introduction of a TQM program towards the end of the sample period that included high levels of employee involvement and formal assurances of job security.$^{16}$ Kleiner, Leonard, and Pilarski (2002) provide a detailed history of these industrial relations developments based on interviews with production managers and union leaders, and estimate an engineering production function to investigate the effect of these changes. As expected, withdrawals of labour are associated with reduced productivity; also as expected, it only takes between one to four months to return to prestrike productivity. Union leadership also seems important, while productivity appears highest when hawks on both sides negotiate. The effects of TQM are if anything 
perverse, which result is held to reflect the manner of its introduction ("a top-down process that never fully won the embrace of the line workers or their front-line supervisors”) (Kleiner, Leonard, and Pilarski, 2002, p 203). It is argued that TQM was bearing fruit at exactly the time management's patience ran out (although the shift back to an authoritarian structure produced improved results in the short run). No less interesting, the authors observe that the effects of TQM may be upwardly biased because they fail to account for the impact of firms that are unsuccessful in implementing it - an inference that might be generalized to other practices pending improved datasets containing information on EI/HPWP dissolutions as well as adoptions.

The results of the more recent U.S. literature on innovative work practices are, then, decidedly mixed both as regards the impact of particular practices and synergies between them. Abstracting from causation issues, positive effects on productivity where observed are only one-half the story, impact on the bottom line is the other. Contingencies may also cast a long shadow in reaching a judgment on the role of such practices. This setting is not altogether propitious for assessing the contribution of the union institution, and it is unsurprising that the mainstream EI/HPWP literature has practiced benign neglect here. Yet recent U.S. evidence does point to some positive interaction effects between individual work practices and unionism. Indeed, even though the nature of some of the associations is at times opaque, it has sometimes been claimed that there is a hierarchy for productivity performance with unionized plants having innovative practices at the top - above those of nonunionized plants with the same set of practices - and at the bottom in traditional workplaces. This conclusion and the use of 
synthetic workplaces to identify hierarchies are premature but the literature has demonstrated potential offsets to the union wage differential.

\section{GERMAN EVIDENCE}

Reflecting the facts of workplace representation, most German studies have focused on the impact of works councils rather than unions, although interest in the union role strictly, the collective agreement external to the establishment - has increased in the wake of Freeman and Lazear's (1995) extension of the voice model. ${ }^{17}$ Before we examine the evidence on the effect of works councils, EI/HPWP, and their interaction on firm performance, however, we sketch some salient characteristics of the German institution(s).

\section{A Primer on Works Councils}

Works councils are mandatory but not automatic - they must be voted in by employees in German establishments with at least five employees. They are found in 16.3 percent of all establishments although they cover 53 percent of the workforce. The frequency of works councils is directly related size of establishment, increasing monotonically from just 9.1 percent in plants with 5-20 employees to 91.7 percent in plants with more than 500 employees (see Addison, Bellmann, Schnabel, and Wagner, 2003).

Works councils have formal information, consultation, and participation rights set down under law. Although the information and consultation rights are more extensive than in other systems, it is the codetermination rights that set the German entity apart. These codetermination (or participation) rights are far reaching and cover such matters as the regulation of working hours, the fixing of job and bonus rates and other forms of 
performance related pay, and the introduction technical devices to monitor employee effort. Recent changes in the law have extended codetermination rights to vocational training measures and the execution of team-working arrangements (see Addison, Bellmann, Schnabel, and Wagner, 2004, pp 395-398).

In each case, the rights of the works council are increasing in employment size. Increased information and consultation rights are first triggered at 21 employees. As examples, the employer has to provide the works council with detailed information on individual personnel movements - codetermination in individual staff movements also applies at this threshold - and, in the separate circumstance of proposed alterations that may entail substantial prejudice to the workforce as a whole (reductions in operations, transfer of departments, amalgamations of establishments, and introduction of new working methods), the employer must first inform and then consult the works council on the proposed alterations. Additional information rights accrue with more than 100 employees: a finance committee has to be set up, charged with the duty to provide the works council with very detailed financial information on the company including its economic and financial situation, production and investment programs, rationalization plans, and the introduction of new work methods. Again, once establishment employment reaches 200, the employer the must make provision for a full-time (or paid) councillor, and as before the number of full-time (and indeed all) councillors is increasing in establishment size. Another size-related condition is the right of the works council in plants with more than 1,000 employees to request the drawing up of guidelines on the technical, personal and social criteria to apply in the engagement, grading, and transfer of workers. 
We mentioned earlier the duty of the employer to consult on alterations involving prejudice to the workforce. In such circumstances, the work council can subsequently negotiate a social plan, by way of compensation. Social plans are a special form of work agreement. These bilateral plant-level agreements between the employer and the works council are prescribed by law and cannot cover wages and other conditions of employment that are fixed or normally determined by collective agreement, unless authorized to do so by the relevant industry- or regional-level collective agreement. However, as Müller-Jentsch (1995, pp 60-61) reports, the contents of works agreements have in practice ranged much further well beyond the terms fixed by the law. Accordingly, although works councils cannot strike and are enjoined to work with the employer in spirit of collaboration - refraining from activities "that interfere with or imperil the peace in the establishment" - the inference would be that separation of distribution from production issues in the German dual system is partial.

Finally, works councils are formally independent of unions, and they are elected by the entire workforce. That said, unions play an important role in the election of works councilors (putting up union lists of candidates in the nomination process), and most works councilors are union members. As a result, works councils have been referred to as "pillars" of union security. Be that as it may, data limitations have, with the exceptions noted below, largely precluded investigation of the union-works council nexus, and of late the union interest has tended to be subsumed under a collective bargaining variable, namely, whether or not the establishment is covered by a collective bargaining agreement. Recalling the discussion of section II, following an external agreement is hypothesized to moderate rent seeking by the works council. 


\section{Works Councils and Establishment Performance}

In a reversal of the pattern of the U.S. literature on worker representation, the early German literature pointed to mostly negative effects of works councils on firm performance. These studies cover a wide range of performance outcomes - total factor productivity, profits, product innovation and R\&D, investment in physical capital and (excessive) quits - do not lack rigor, ${ }^{18}$ and contain detailed information on establishment characteristics and sometimes union density (on the interaction of union density and works councils, see FitzRoy and Kraft, 1990; Schnabel and Wagner, 1994) have the disadvantage of small sample size - typically around 100 firms/plants - raising obvious issues of external validity. (For a review of this literature, see Addison, Schnabel, and Wagner, 2004.)

More recently, analysts have been able to work with much larger data sets, namely, the Hannover Firm Panel, the NIFA-Panel, and the nationally representative Establishment Panel of the Institute for Labor Market Research, or IAB Establishment Panel. The Hannover Panel is a stratified random sample of all manufacturing plants with at least five employees in the German state of Lower Saxony, 1994-97. It comprises around 1,000 establishments in 1994, declining to a little over 700 establishments in 1997 because of sample attrition. The NIFA-Panel is a survey of all establishments in the German machine-tool industry, 1991-98. The sample base is around 6,000 firms and the realized sample approximates 1,500 per wave. Finally, the IAB Establishment Panel has been conducted each year from 1993 (for eastern Germany from 1996 onward). It is based on a stratified random sample - strata for 16 industries and 10 size classes - from 
the population of all establishments with at least one employee covered by social insurance. The panel is created to serve the needs of the Federal Labour Agency, and so its focus is on employment-related matters. The two other surveys contain somewhat richer establishment information, and, in the case of (one wave of) the NIFA-Panel, subjective data on works council 'type' and 'degree of works council involvement' from a management perspective (see Dilger, 2002). That said, the IAB Establishment Panel contains the only nationally representative longitudinal sample of establishments and unlike the other two data sets it is possible to proxy the capital stock. ${ }^{19}$

Table 2 reports results from a selection of studies using two of the new data sets. It is not meant to be fully inclusive of the literature for two reasons. First of all, it is deliberately 'light' on the more descriptive labour turnover literature, the thrust of which is nonetheless conveyed by the study summarized in row 1 and 2 of the table. ${ }^{20}$ Second of all, it is only one-half the research that we consider: Table 4 reviews studies that also consider EI/HPWP (to include training).

(Table 2 near here)

The most notable feature of the studies using these large datasets is their more favourable evaluation of works council impact. For the two studies using the Hannover Firm Panel (rows 1 and 2 of the table), the pro-productive effect of the works council depends on establishment size and collective bargaining regime, respectively. Addison, Schnabel, and Wagner (2001) report that works council presence is associated with higher value-added per employee only for the all-firm sample; for smaller establishments with between 21 and 100 employees the association is statistically insignificant. This result might reflect a theme of the earlier literature to the effect that for smaller firms the 
advantages of codetermination may be lower and the costs higher than for larger firms. But the authors' own justification for focusing on this sub-sample is two-fold: first, lacking information on works council type, it makes sense to estimate the effect of the entity for a sample in which the rights/powers of the works council are a datum; second, only in this employment range are establishments with and without works councils present in reasonable numbers, as opposed to being dominant (see above). Apart from there being no evidence of higher productivity within this sample, Addison, Schnabel, and Wagner also report that works councils are not associated with reduced labour turnover in this sub-sample either, although they obtain the conventional effect for the all-establishment sample.

For their part, Hübler and Jirjahn (row 2) emphasize not establishment size but instead whether or not the establishment is covered by a collective agreement. They seek to test the argument of Freeman and Lazear (1995) that where a works council is embedded in a (external) collective bargaining arrangement, the control exerted by the union and the employers' federation can serve to dissipate distributional squabbles at the workplace allowing the voice effects to realized. As can be seen, they report that proproductive works council effects are only found where the establishment follows a collective agreement.

The Hannover Firm Panel does not contain information on the capital stock, raising the potential problem of omitted variables bias. However, the capital stock may be inferred from data on replacement investment in the IAB Establishment Panel. Using this information, the study by Frick (2003) in row 3 of the table provides one of the first estimates of a works-council-augmented production function for Germany (see also 
Addison, Kraft, and Wagner, 1993; FitzRoy and Kraft, 1987). The magnitude of the works council 'effect' is highly reminiscent of the union effects reported by Brown and Medoff (1978) some 25 years earlier for the United States. Plants with works councils have 25-30 percent higher productivity than their counterparts without works councils. Drawing on secondary evidence that wages are higher in works council plants, Frick (2003, p 448) nevertheless cautions that these effects may not compensate firms for the additional costs. $^{21}$

The next two studies summarized in Table 2 that also use the IAB Establishment Panel question this large productivity effect of works councils (as indirectly does the final study in row 6). Substituting sales for value added on data grounds - for example, respondents often fail to answer the materials cost question in the panel survey ${ }^{22}-$ and restricting the sample to plants with between 21 and 100 employees, Schank, Schnabel, and Wagner (2004) estimate frontier productions for separate samples of firms with and without works councils, 1993-2000. They report no statistically significant differences in the technical efficiencies of the median plant in the two samples. Using a very different approach, the study by Addison, Bellmann, Schnabel, and Wagner (2004) in row 5 of the table seeks to carefully match plants that witnessed the formation of works councils in 1998 and those that remained free of works councils for the entire sample period (19962000). For their four outcome indicators, including a proxy for productivity growth, they report no statistically significant differences in mean performance among the two types of firms. This study represents one attempt to deal with selection problems that dog the other estimates in Table 2. 
The final study in row 6 of the table is relevant from the perspective of another type of potential bias attaching to both cross section and (balanced) panel estimates alike, namely, the problem that we are observing survivors. Underperforming works council plants may have been evolved out of the system, leaving an unrepresentative sample of survivors. The study by Addison, Bellmann, and Kölling (2004) does find that other things being equal works council firms do fail at higher rates than their non-works council counterparts. Although this hints at survival bias, we would caution that this evidence is indirect (i.e., survivability should be modelled simultaneously with the performance equation), that the failure rates in question are low, and that the number of industry controls is for statistical reasons quite limited.

(Table 3)

By the same token, one should continue to be wary of the ambitious proproductive works council effects provided in row 3 of the table. In Table 3, we present summary results from fitting a translog production function to pooled data for 1997-2000 from the IAB Establishment Panel. The dependent variable is sales (rather than value added) and the sample is restricted to firms with 21-100 employees, other than in the last row of the table where pooled estimates for the entire sample of establishments with five or more employees are given in bold for purposes of comparison. Although works council 'effects' are in our view still uncomfortably large, ${ }^{23}$ note first the differences between the coefficient estimates in the pooled regressions for the sample comprising plants of all sizes and the sub-sample of establishments with 21-100 employees. Next observe the generally insignificant coefficients for the all-important German manufacturing sector in both pooled and cross-section data. Then observe the variation in 
the coefficient estimates in cross section. Finally consider that there are no a priori grounds for expecting major differences in works council effects as between manufacturing and services. Taken in conjunction with the evidence in Table 2, we would argue that although the early German literature most likely encouraged an overly negative view of works council operation some of the more recent estimates are likely to do exactly the opposite.

\section{EI/HPWP, Works Councils and Firm Performance}

As with the U.S. evidence on unions, however, the issue of works council impact does not end here. Rather more than in the United States perhaps, discussion of the effects of worker representation in Germany has become linked with those of innovative work practices. Table 4 provides a summary of the diverse literature. The themes of this literature, mostly based on the three large-scale datasets introduced earlier, include works council type, incentivization issues, complementarities, and training. Together the studies point to circumstances in which works councils may be associated with favourable productivity outcomes.

\section{(Table 4 near here)}

We begin with the study by Frick (2002) (row 1) which, although descriptive, is notable for its attempts to investigate directly the impact of works council type (see also Dilger, 2002). The only large-scale data set to contain such information is the (sixth wave of the) NIFA-Panel. As can be seen, Frick's results using this information are mixed. Thus, HPWPs are not significantly more numerous in works council plants than others and while 'more involved' councils tend to have more HPWPs those works councils dubbed 'antagonistic' by management have the most. Similarly, while HPWPs are 
reported in the author's multiple classification analysis to benefit firm performance, they are also said to be associated with reduced labour demand.

Unlike the other studies reviewed in Table 4, the analysis in row 2 is based on an early sample of just 65 metal working firms. This dataset was first used by FitzRoy and Kraft (1985, 1987, and 1990) in a series of studies charting the impact of works councils on profitability, total factor productivity, and innovation. Adverse works council effects were reported for all outcome indicators in systems of equations that typically endogenized works council presence. But in this their most recent investigation, FitzRoy and Kraft (1995) report find that works council effects on labor productivity are actually positive and statistically significant in regimes practicing profit sharing, even if they are negative and well determined in other regimes. The authors attribute the positive works council effect to cooperative labour relations.

FitzRoy and Kraft find that profit sharing is associated with sharply higher productivity - in both single and simultaneous equation treatments. This result is not generally found in the large-scale data sets; for example, neither Frick (2002) (row 3, Table 2), using the IAB Establishment Panel, nor Hübler and Jirjahn (2003) (see row 2, Table 2), using the Hannover Firm Panel, observe discern this outcome. ${ }^{24}$ Abstracting from measurement issues (on which more below), an interesting extension of the incentives discussion is profit sharing for executives. The study by Jirjahn in row 3 of Table 4 finds that managerial profit sharing strongly improves productivity, suggesting that it attenuates agency problems. But this issue is only part of the story; the other is works council presence and its interaction with executive profit sharing. As can be seen from the table, the coefficient estimate for works council presence is positive and 
statistically significant while that for the interaction term is negative and again well determined. Focusing on the latter result, Jirjahn argues it is consistent with two hypotheses: either profit sharing reduces the commitment value of agency in circumstances where works councils cannot foster trust and loyalty absent the cooperation of management, or management rent seeking is curbed by profit sharing and the works council is not important for building cooperation in situations of reduced opportunism on the part of management. Although these empirical findings have yet to be replicated in other data sets, central to Jirjahn's approach is the notion that the management environment of the firm matters in evaluating works council impact. His approach is also very much in the spirit of collective voice model, even if the contribution of the works council is not transparent. This latter remark in turn reflects some negative correlations noted in the literature such as that between team work and works councils, and most of all the simple fact that the magnitude of the negative interaction term between works councils and executive profit sharing exceeds that of the positive point estimate for works council presence.

The remaining three studies in Table 4 follow a common methodology suggested in part by Black and Lynch (2001) (see row 5, Table 1) and use the IAB Establishment Panel. Especial emphasis is placed upon on selection issues and unobserved plant heterogeneity. The study by Wolf and Zwick (2002) in row 4 of the table provides the template for the other two studies. Wolf and Zwick focus on the productivity of HPWPs. They identify seven such practices, which are reduced to two independent factors termed "organizational changes" (participatory practices such as team work) and 'incentives' (e.g., profit sharing) - using principal components analysis. The authors fit 
an augmented Cobb-Douglas production function to cross-section data for 1999, including a selectivity-adjusted specification. They also fit a Cobb Douglas function to data for 1996-99 using panel estimation methods, and derive a fixed time invariant establishment-specific effect for each plant after Black and Lynch, which values are then regressed on the time invariant covariates - including organizational changes and incentives - again allowing for selection. Note that the dataset only enables the authors to identify whether or not the innovative practices were present at a point in time, not when they had been introduced.

As shown in Table 4, both selection and accounting for structural differences matter. The positive effect on productivity of incentive mechanisms, observed in both cross section and in the panel, seem to result from such schemes being introduced in times of plenty, when firms are doing well as. That is, after correction for the endogeneity of such measures, the variable is no longer statistically insignificant. For their part, the effect of organizational changes is statistically insignificant in cross section, with and without correction for selection. However, the coefficient estimate is both positive and well determined in the panel estimates, and after controlling for selection strengthens somewhat. The main message of this study, therefore, is that firms which introduce organizational changes seemingly have unobserved time invariant characteristics that decrease their productivity. Expressed differently, participatory work practices raise productivity.

The results pertaining to incentive mechanisms clearly qualify the results of FitzRoy and Kraft (1995) (row 2 of Table 4) who control for the endogeneity of profit sharing but not unobserved firm heterogeneity. Wolf and Zwick nevertheless do argue 
that works councils work - the coefficient estimate for the variable is positive and statistically significant in the second step panel procedure - even they do not seem to influence organizational change. (Our wider concern with the lack of temporal variation in both the HPWP measures and works council presence is revisited below.) Finally, two other results from the cross section part of this study might be noted. Not only is there no evidence of synergies between the two sets of innovative practices but also very few instances of complementarities between their components.

The role of the work council is secondary in Wolf and Zwick. In the next study in the table, it shares equal billing with innovative work practices. Zwick (2003) (row 5) considers just those practices found to be statistically significant in Wolf and Zwick namely, organizational changes, now termed 'participation' - and considers their impact on productivity over the same interval, albeit using a different panel estimator for the (first stage) production function and now controlling for the endogeneity of works council presence (as well as that of the participation variable). Other differences reside in the measurement of capital and the construction of the participation measure.

Zwick’s second-step regression results for a specification in which works councils are assumed exogenous indicates that the innovative work practice(s) is positive and well determined, elevating productivity by 25 percent. However, accounting for the nonrandom distribution of works councils in an endogenous switching regression model shows that the pro-productive effect of participatory work practices (or one such practice) only obtains in works council firms. Although the story is similar to that told by Wolf and Zwick - in the sense that innovatory practices are conceived to rectify structural productivity deficits - the main result is very different: innovations only bear fruit in 
works council regimes. This result is analogous to that of Cooke (1994) for the United States (see Table 1, row 4). No other German study reaches so stark a conclusion. Unfortunately, the coefficient estimate for the participation variable in works council plants is only marginally significant so that it is not clear that it differs from the statistically insignificant coefficient estimate for participation in the sample of plants without works councils.

One of the routes through which works councils and all voice institutions are supposed to influence productivity is by encouraging investments by the firm in training. Although the German literature has dwelt at some length on the labour turnover issue, there has been little direct analysis of further training. A rare exception is final study in row 6 of Table 4, in which Zwick (2002) examines the determinants of such training and its impact on labour productivity. As in the two preceding studies, the basic framework is again a mix of cross section and two-stage panel estimation with endogenous training. In addition to detailed establishment controls, the equations include three other innovative work practices. These are identical to those previously grouped under 'participation' in the row 5 study, namely, a shifting of responsibilities to lower levels in the hierarchy (termed 'employee participation'), the presence of teamwork and self-directed groups, and work groups/units with their own costs and results accounting. These three practices are now treated as exogenous, as is works council presence.

Zwick finds that training intensity (share of trained employees in the workforce) as well as several types of training (especially formal external training) have positive effects on productivity in cross section and in the second-step panel estimation procedure. In both cases, accounting for the endogeneity of training either by predicting training 
intensity or by including an inverse Mills ratio term (the probability of a training presence) in the regression tends to increases the magnitude of well determined coefficient estimates, suggesting that there is a greater tendency to train when productivity is low. The effect of the panel estimation is also to increase the measured impact of training. But of the other innovative work practices none is statistically significant in cross section and just one (shifting of responsibilities to lower levels in the hierarchy) is significant in most of the second-step panel estimates. A positive association between works council presence and productivity is discerned in cross section but in the second-step panel estimates the coefficient estimates for this variable are statistically insignificant throughout. Unlike the work practices, however, work councils are included as a determinant of training (i.e. training intensity) and their influence is positive and statistically significant, a result that is ascribed to the absence or attenuation of hold up this time on the part of employers - in works council regimes.

The increasing sophistication of the German studies in the attempt to control for selection into either innovative working practices, including training, or works council status while taking account of unobserved plant heterogeneity has to be measured against the limitations of the data. As far as selection into works council status is concerned, we do know that works council presence is not random but is related to establishment size and the structure of the work force, among other things. However, the introduction or presence of a works council is not the result of a rational choice made by the owners or managers of an establishment based on comparing costs and benefits; rather, it is the results of actions taken by the employees. Employee action might well be related to the past performance of the establishment, but whether an establishment has a works council 
at a point in time should not be viewed as caused by contemporaneous productivity. This might suggest that one can treat works council status as exogenous to the establishment, not least given the difficulties of identifying the works council equation in a convincing manner. Identification issues also loom large when it comes to the identifying equations for innovative work practices, including training. Understandably, analysts have switched between treating works councils and innovative work practices as endogenous according to the emphasis of the particular study, but this approach has produced some inconsistencies.

More might be expected from panel estimates that control for unobserved plant heterogeneity. Unfortunately, there is the problem that that works council status tends not to change over time - for example, in balanced panels from the IAB Establishment Panel, 1997-2000, around two percent of plants change their works council status. And as regards the innovative works practices, we lack longitudinal data altogether. Given the lack of temporal variation in works councils status and HPWPs for either reason, the Black-Lynch procedure has found favour. The problem is course that the estimated coefficients for works councils and innovative practices in the second step may be biased by reason of correlation between these variables and unobserved time-invariant establishment characteristics. For example, as noted earlier, better managers are more likely to be observed in plants with HPWPs so that what appears to be a productivity effect of innovative practices is good management. A further problem is that if we lack longitudinal information on HRWPs, we cannot assume that their frequency did not change materially over the sample period in question. 
Despite these and other concerns (not least the lack of information on the numbers of workers covered by HPWPs and on 'type' of works council), the German literature suggests that works councils and innovative practices may have favorable effects on productivity. Indeed, we have reviewed material that attributes major productivity gains to each. But average wage council effects are unlikely to be strong. We mainly base this conclusion on estimates obtained for samples of plants employing between 21 and 100 workers where there is a 'balanced' representation of works council and non-works council establishments and where the powers of works councils are a datum. As far as HPWPs are concerned, it would be idle to claim that there is agreement as to which measures work. The disputation over profit sharing is the main case in point. Not surprisingly, therefore, when we come to consider the interaction between works councils and innovative work practices the situation is not transparent. But we think the evidence supports the notion that innovative work practices allow works council firms to achieve improved productivity if not necessarily higher productivity than non-works council firms.

One further caveat is the near exclusive focus in recent German work on the productivity outcome. We have no information on possible increases in labour costs occasioned by operating HPWPs, as suggested by some U.S. research. We do know that wages are higher in works council regimes (see Table 2, row 1), but we can infer little from this because there is no indication that works council presence has any effect on the excess of wages over those laid down under collective agreements. It remains a possibility that works councils may cause wage or incentive pay drift, or that they inflate nonwage costs, but there is as yet no real evidence to substantiate this. 
Two final issues are whether works councils and HPWRs are substitutes or complements, and the status of the often-encountered argument that German employers would have to invent works councils were they not legislated. There is evidence to favour both substitutability and complementarity. Examples of the former include the finding of a negative association between team-working and works council presence and the greater frequency of HPWPs in the absence of works councils (or, in their presence, where works councils are antagonistic). Examples of the latter are the positive association between works councils and group incentives and training.

The idea that works councils would have to be invented were they not legislated is certainly not a finding that leaps from the pages of the early works council literature or even from the more recent literature without qualification. One such qualification may be plant size. Unfortunately, it is difficult to test the argument that works councils are beneficial in large establishments (such as those of the former Krupp organization). This is because nearly all such plants are covered by works councils, and conversely for small plants. Another qualification is that establishments may need to be covered by a collective agreement to blunt the bargaining or hold-up implications of codetermination. A final set of qualifications would presumably involve the contribution of innovative working practices and cooperative relations. Overall, then, the statement attributed to Herr Beitz is not particularly informative.

\section{CONCLUSIONS}

We have examined the effects of worker representation in unions and works councils, and of employee involvement/innovative work practices - and their interaction - on firm 
performance. In view of the doubts concerning the performance effects of high performance work practices and controversies surrounding the effects of worker representation - both of which aspects are addressed in our analysis - the results of the exercise might have been predicted to be both compartmentalized and pessimistic. But we have largely interpreted the worker representation literature as indicating that the effect of unions on productivity are likely to be small on average so that we should look to factors such as innovative work practices in explaining the diversity in the effects of worker representation in different settings. Expressed in terms of the theoretical conjectures on unions, the interaction of worker representation and HPWPs provides a practical means of peering inside the union black box. We would incline to the same interpretation of the works council institution, even if unobserved works council type may turn out to be a more important source of variation in overall performance.

We reported evidence of positive HPWP effects in both countries and also of positive interactions with worker representation. The suggestion is, then, that combinations of innovative practices and worker representation can yield substantial productivity gains. In Germany, HPWPs may be an important means of restoring competitiveness and works councils may assist in their introduction. Yet there should be no pretense to precision in all of this in the sense of the literature having uncovered a well determined hierarchy for productivity performance, or blue-print for the future of unions in particular. This is not unexpected and reflects the limitations of both literatures namely, the notion of collective voice and the high performance paradigm - underscored throughout by pronounced measurement difficulties. Here the cautionary remarks of 
Wood and de Menezes (1998) based on the British experience are also apropos for the United States and Germany. 


\section{ENDNOTES}

*University of South Carolina, Universidade de Coimbra/GEMF, and IZA Bonn

1 The composite employee involvement/innovative work practices has no settled meaning. I will use it to include profit-sharing/share ownership arrangements, consultative bodies, team working, quality circles and problem-solving groups, briefing groups, systematic use of the management chain to communicate, and regular meetings with senior management plus benchmarking, total quality management (TQM), training, job security, job rotation, and payment for skill acquisition, inter al.

${ }^{2}$ There is inevitably some artificiality in this separation. For example, some models in the spirit of collective voice stress that successful employee involvement required the presence of a union before workers will practice consummate as opposed to perfunctory cooperation (Levine and Tyson, 1990).

${ }^{3}$ For an exhaustive set of tests of the hypothesis for Britain, see Machin and Wood (2005).

${ }^{4}$ For the public goods argument to have force, two further conditions must be met - both of which are contained in Freeman (1976, p. 362). First, costs must be incurred in using external markets: if quitting were costless, the individual worker could simply choose the employer whose working conditions most closely approximated his/her own preferences. Second, the workplace must continue to be buffeted by unforeseen shocks that change the nature of the workplace in an informational context; otherwise, there would be no need for the union's demand-revealing function after the formative match between employer and worker.

${ }^{5}$ The notion that unions might help increase training has formally been allied to contract enforcement by Dustmann and Schönberg (2004), who argue that the unavailability/infeasibility of long-term wage agreements means that training will be underprovided in regular markets and that unions move (apprenticeship) training closer to the social optimum by guaranteeing trained workers at least the union wage in the future. Since wage compression is also involved, unions facilitate firm-financed general training in this model (see also Acemoglu and Pischke, 1999).

${ }^{6}$ The equation assumes constant returns to scale, which constraint is relaxed by adding a measure of establishment size, $\ln L$, to the regressors.

${ }^{7}$ For an attempt to detect some systematic patterns in production function studies covering the cement industry, building construction, government bureaus, schools, hospitals, and textiles, see Addison and Hirsch (1989).

${ }^{8}$ While confirming Hirsch's (1991) R\&D results for the United States, Menezes-Filho, Ulph, and Van Reenen (1998) cannot replicate them for Britain. Indeed, Menezes-Filho and Van Reenen (2003) report that the results are not robust for continental Europe either. So, although the association between unionism and $R \& D$ is negative in this bloc as 
well, it is again seemingly driven by unions being concentrated in older, low-tech industries.

${ }^{9}$ For example, Hirsch (1991) finds that the negative effect of union coverage on productivity growth in his sample of 572 publicly quoted companies falls precipitously and approach zero with the addition of successively more detailed industry controls. Having corrected for positively correlated firm residuals across time, the coefficient estimates for union coverage in specifications with detailed industry controls become statistically insignificant.

${ }^{10}$ But for evidence of higher closure rates among union establishments in Britain, see Addison, Heywood, and Wei (2003); Bryson (2004). The German evidence is noted below.

${ }^{11}$ Huselid (1995) reported that his additive indices of HPWPs were associated with reduced labour turnover, higher sales per employee, and improvements in (one measure of) financial performance among his cross-section sample of 986 firms.

${ }^{12}$ For example, their capital stock measure is constructed from information on the book value of assets in the base year (1987) and new investments in each year, net of an estimate of the fraction of capital that is used up each year. In additional to longitudinal measures of the firm's capital stock - and capital vintage - the dataset contains information on the average education of the workforce, recruitment strategies, the number of employees trained, and computer usage, etc.

${ }^{13}$ In addition to the within estimator, the authors use a GMM estimator in the first step to deal with biases stemming from the endogeneity of capital, labour, and materials.

${ }^{14}$ The authors note that, although individually only one interaction term was statistically significant, they rejected at the .05 level the joint null that all four interactions were zero.

15 The authors provide a parallel analysis of earnings and earnings change, not summarized in the table. The results are mixed, meaning that not all innovations influence productivity and earnings in the same way.

${ }^{16}$ For a matching model of TQM introduction, see Easton and Jarrell (1998).

${ }^{17}$ For industry-level studies of union impact see, for example, Schnabel (1989); Schnabel and Wagner (1992).

${ }^{18}$ Among the best examples are the papers by FitzRoy and Kraft (1985, 1987, and 1990) that deploy systems of equations in examining profitability, total factor productivity, and innovation, respectively, in a small sample of a little over 60 metal working firms. The unifying theme of all three papers is a managerial pressure/managerial competence model: efficient managers are able to elicit greater effort from their workforces without interference from works councils and are also able to institute adequate systems of 
communication and decision-making and avoid (the delays associated with) works councils, partly by paying higher wages. As can be seen in Table 4, below, this model is qualified in a more recent study by the authors (FitzRoy and Kraft, 1995).

${ }^{19}$ For further information on all three data sets, see respectively Brand, Carstensen, Gerlach, and Klodt (1996), Widmaier (2001), and Kolling 2000).

${ }^{20}$ But for an interesting study of quits, hires, and labour fluctuation using the NIFA-Panel that exploits works council type, see Dilger (2002).

${ }^{21}$ Most German studies report that the simple association between works councils and wages is positive and statistically significant. But investigation of the excess of wages over those agreed to in collective agreements does not point in the same direction (see Addison, Schnabel, and Wagner, 2001, in row 1 of Table 1); see also FitzRoy and Kraft (1985).

${ }^{22}$ No less important, the materials costs - measured as the percentage share of sales represented by materials costs - often seem to be little more than informed guesses.

${ }^{23}$ Quantile regression analysis suggests that the large pro-productive effects for the allestablishment sample in the Hannover Firm Panel are driven by highly productive plants; that is, they are detected only in plants at the top end of the conditional productivity distribution (see Addison, Schank, Schnabel, and Wagner, 2004). Our preliminary analysis of the IAB Establishment Panel points to similar results - at least for the key manufacturing sector. The suggestion may be that only highly competent managers can cooperate with a works council in a way that materially advances productivity.

${ }^{24}$ The exception is that the latter do find a positive effect of profit sharing on labour productivity for the uncovered sector which they speculate reflects union opposition to profit sharing. 


\section{REFERENCES}

ACEMOGLU, D. and PISCHKE, J-S. (1999). The structure of wages and investment in general training. Journal of Political Economy, 107, pp. 539-72.

APPLEBAUM, E. and BATT, R. (1984). The New American Workplace: Transforming Work Systems in the United States. Ithaca, NY: ILR Press.

ADDISON, J.T. and BELFIELD, C.R. (2004). Union voice. Journal of Labor Research, 25, pp.563-96.

ADDISON, J.T., BELLMANN, L., and KÖLLING, A. (2004). Works councils and plant closings in Germany. British Journal of Industrial Relations, 42, pp. 125-48.

ADDISON, J.T., BELLMANN, L., SCHNABEL, C., and WAGNER, J. (2003). German works councils old and new: incidence, coverage and determinants. Schmollers Jahrbuch 123, 339-58.

ADDISON, J.T., HEYWOOD, J.S., and Wei, X. (2003). New evidence on unions and plant closings: Britain in the 1990s. Southern Economic Journal, 69, pp. 822-41.

ADDISON, J.T., and HIRSCH, B.T. (1989). Union effects on productivity, profits and growth: has the long run arrived? Journal of Labor Economics, 7, pp. 72-105.

ADDISON, J.T., KRAFT, K., and WAGNER, J. (1993). German works councils and firm performance.” In B.E. Kaufman and M.M. Kleiner (eds.), Employee Representation: Alternatives and Future Directions. Madison, WI: Industrial Relations Research Association, pp. 305-38.

ADDISON, J.T., SCHANK, T., SCHNABEL, C., and WAGNER, J. (2003). German works councils in the production process. Discussion Paper No. 812. Bonn: Institute for the Study of Labour/IZA.

ADDISON, J.T., SCHANK, T., SCHNABEL, C., and WAGNER, J. (2004). Works councils, labour productivity and plant heterogeneity: evidence from quantile regressions. Discussion Paper No. 1414. Bonn: Institute for the Study of Labour/IZA.

ADDISON, J.T., SCHNABEL, C., and WAGNER. (2004). The course of research into the economic consequences of German works councils. British Journal of Industrial Relations, 42, pp. 255-81.

ADDISON, J.T, and TEIXEIRA, P. (2004). The effect of worker representation on employment behaviour in Germany: another case of -2.5\%. Discussion Paper No. 1188. Bonn: Institute for the Study of Labour/IZA. 
BALDWIN, C.Y. (1983). Productivity and labour unions: an application of the theory of self-enforcing contracts. Journal of Business, 56, pp. 155-85.

BLACK, S. and LYNCH, L.M. (2000). What's driving the new economy: the benefits of workplace innovation. NBER Working Paper No. 7479 (Revised October 2000).

BLACK, S. and LYNCH, L.M. (2001). How to compete: the impact of workplace practices and information technology on productivity. Review of Economics and Statistics, 83, pp. 434-45.

BRAND, R., CARSTENSEN, V., GERLACH, K., and KLODT, T. (1996). The Hannover panel. Discussion Paper No. 2, University of Hannover, May.

BROWN, C. and MEDOFF, J.L. (1978). Trade unions in the production process. Journal of Political Economy, 86, pp. 355-78.

BRYSON, A. (2004). Unions and workplace closure in Britain. British Journal of Industrial Relations, 42, pp. 283-302.

CAPPELLI, P. and NEUMARK, D. (2001). Do high-performance work practices improve establishment-level outcomes? Industrial and Labor Relations Review, 54, pp. 737-75.

CAVANAUGH, J.K. (1998). Asset-specific investment and unionized labour. Industrial Relations, 37, pp. 35-50.

CLARKE, K.B. (1984). Unionization and firm performance: the impact on profits, growth, and productivity. American Economic Review, 74, pp. 893-919.

COOKE, W.N. (1992). Product quality improvement through employee participation: the effects of unionization and joint union-management administration. Industrial and Labor Relations Review, 46, pp. 119-34.

COOKE, W.N. (1994). Employee participation programmes, group-based incentives, and company performance: a union-nonunion comparison. Industrial and Labor Relations Review, 47, pp. 594-609.

DILGER, A. (2002). Ökonomik betrieblicher Mitbestimmung, Munich and Mering: Rainer Hampp Verlag.

DiNARDO, J. and LEE, D.S. (2002). The impact of unionization on establishment closure: a regression discontinuity analysis of representation elections. Working Paper No. 8993, National Bureau of Economic Research 
DUSTMANN, C. and SCHÖNBERG, U. (2004). Training and union wages. Discussion Paper No. 1435. Bonn: Institute for the Study of Labour/IZA.

EASTOM, G.S. and JARRELL, S.L. (1998). The effects of total quality management on corporate performance: an empirical investigation.” Journal of Business, 71, pp. 253-305.

FALLICK, B.C. and HASSETT, K.H. (1999). Investment and union certification. Journal of Labor Economics, 17, pp. 570-82.

FITZROY, F. and KRAFT, K. (1985). Unionization, wages, and efficiency: theories and evidence from the U.S. and West Germany, Kyklos, 38, pp. 537-54.

FITZROY, F. and KRAFT, K. (1987). Efficiency and internal organization: works councils in West German firms. Economica, 54, pp. 493-504.

FITZROY, F. and KRAFT, K. (1990). Innovation, rent-sharing and the organization of labour in the Federal Republic of Germany, Small Business Economics, 2, pp. 95103.

FITZROY, F. and KRAFT, K. (1995). On the choice of incentives in firms. Journal of Economic Behavior and Organization, 26, pp. 145-60.

FORTH, J. and MILLWARD, N. (2004). High involvement management and pay in Britain. Industrial Relations, 43, pp. 98-119.

FREEMAN, R.B. (1976). Individual mobility and union voice in the labour market. American Economic Review, Papers and Proceedings, 66, pp. 361-68.

FREEMAN, R.B., KLEINER, M.M., and OSTROFF, S. (2000). The anatomy of employee involvement and its effects on firms and workers. Working Paper 8050, National Bureau of Economic Research.

FREEMAN, R.B. and LAZEAR, E.P. (1995). An economic analysis of works councils. In J. Rogers and W. Streeck (eds.), Works Councils, Consultation, Representation and Cooperation in Industrial Relations. Chicago, IL: University of Chicago Press.

FREEMAN, R.B. and MEDOFF, J.L. (1984). What Do Unions Do? New York, N.Y.: Basic Books.

FRICK, B. (2002). High performance work practices und betriebliche Mitbestimmung: komplementär oder substantive? Industrielle Beziehungen, 9, pp. 79-102. 
FRICK, B. and MÖLLER, I. (2003). Mandated works councils and firm performance: labour productivity and personnel turnover in German establishments. Schmollers Jahrbuch, 123, pp. 435-54.

GERLACH, K. and JIRJAHN, U. (2001). Employer provided further training: evidence from German establishment data. Schmollers Jahrbuch, 121, pp. 139-64.

GODARD, J. (2004). A critical assessment of the high-performance paradigm. British Journal of Industrial Relations, 42, pp. 349-78.

HANDEL, M.J. and LEVINE, D.I. (2004). Editor's introduction: the effects of new work practices on workers. Industrial Relations, 43, pp. 1-43.

HIRSCH, B.T. (1991). Labor Unions and the Economic Performance of U.S. Firms. Kalamazoo, MI: Upjohn Institute for Employment Research, 1991

HIRSCH, B.T. (2004). What do unions do for economic performance? Journal of Labor Research, 25, pp. 415-55.

HIRSCH, B.T. and MORGAN, B.A. (1994). Shareholder risk and returns in union and nonunion firms. Industrial and Labor Relations Review, 47, pp. 302-18.

HÜBLER, O. and JIRJAHN, U. (2003). Works councils and collective bargaining in Germany: the impact on productivity and wages. Scottish Journal of Political Economy, 50, pp. 471-91.

HUSELID, M.A. (1995). The impact of human resource management practices on turnover, productivity, and corporate financial performance. Academy of Management Journal, 38, pp. 400-422.

HUSELID, M.A. and BECKER, B.E. (1996). Methodological issues in cross-sectional and panel estimation of the human resource-firm performance link. Industrial Relations, 35, pp. 400-422.

ICHNIOWSKI, C. (1990). Human resource management systems and the performance of U.S. manufacturing businesses. Working Paper No. 3349, National Bureau of Economic Research.

ICHNIOWSKI, C., KOCHAN, T.A., LEVINE, D., OLSON, C., and STRAUSS, G. (1996). What works at work: overview and assessment.” Industrial Relations, 35, pp. 299-333

ICHNIOWSKI, C., SHAW, K., and PRENNUSHI, G. (1997). The effect of human resource management practices on productivity: a study of steel finishing lines. American Economic Review, 87, pp. 291-313. 
JIRJAHN, U. (2003). Executive incentives, works councils and firm performance. Schmollers Jahrbuch, 123, pp. 397-421.

KLEINER, M.M., LEONARD, J.S., and PILARSKI, A.M. (2002). How industrial relations affects plant performance: the case of commercial aircraft manufacturing. Industrial and Labor Relations Review, 55, pp. 195-218.

KÖLLING, A. (2000). The IAB establishment panel. Schmollers Jahrbuch, 120, pp. 291300.

LaLONDE, R.J., MARSCHKE, G. and TROSKE, K. (1996). Using longitudinal data on establishments to analyze the effects of organizing campaigns in the United States. Annales d'Economie et de Statistique, 41/42, pp. 155-85.

LEVINE, D.I. (1995). Reinventing the Workplace: How Business and Employees Can Both Win. Washington, DC: The Brookings Institution.

LEVINE, D.I. and TYSON, L.D. (1990). Participation, productivity, and the firm's environment.” In A.S. Blinder (ed.), Paying for Productivity. Washington, D.C.: The Brookings Institution.

MACHIN, S. and WOOD, S. (2005). HRM as a substitute for trade unions in British workplaces. Industrial and Labor Relations Review (forthcoming).

MALCOMSON, J.M. (1983). Trade unions and economic efficiency. Economic Journal, 93, pp. 50-65.

MENEZES-FILHO, N. and VAN REENEN, J. (2003). Unions and innovation: a survey of the theory and empirical evidence. In J.T. Addison and C. Schnabel (eds.), International Handbook of Trade Unions. Cheltenham, England, and Northampton, Mass.: Edward Elgar.

MENEZES-FILHO, N., ULPH, D., and VAN REENEN, J. (1998). R\&D and union bargaining power: evidence from union companies and establishments. Industrial and Labor Relations Review, 52, pp. 45-63.

MILGROM, P. and ROBERTS, J. (1995). Complementarities and fit: strategy, structure and organizational change in manufacturing. Journal of Accounting and Economics, 19, pp. 179-208.

MÜLLER-JENTSCH, W. (1995). Germany: from collective voice to co-management.” In J. Rogers and W. Streeck (eds.), Works Councils, Consultation, Representation and Cooperation in Industrial Relations. Chicago, IL: University of Chicago Press. 
SCHANK, T., SCHNABEL, C., and WAGNER, J. (2004) Works councils: sand or grease in the operation of German firms. Applied Economic Letters, 11, pp. 15961.

SCHNABEL, C. (1989). Zur ökonomische Analyse der Gewerkschaften in der Bundesrepublik Deutschland. Frankfurt: Peter Lang.

SCHNABEL, C., and WAGNER, J. (1992). Unions and innovation: evidence from German micro data. Economics Letters, 39, pp. 369-73.

SCHNABEL, C., and WAGNER, J. (1994). Industrial relations and trade union effects on innovation in Germany. Labour, 8, pp. 489-503.

WIDMAIER, U. (2001). The German mechanical engineering industry and the NIF panel. Schmollers Jahrbuch, 121, pp. 275-84.

WOOD, S. and DE MENEZES , L, (1998). High commitment management in the U.K.: evidence from the Workplace Industrial Relations Survey and Employers' Manpower and Skills Practices Survey. Human Relations, 51, pp. 485-515.

WOLF, E. and ZWICK, T. (2002). Reassessing the impact of high performance workplaces. Discussion Paper No. 02-07. Mannheim: Centre for European Economic Research/ZEW.

ZWICK, T. (2002). Continuous training and firm productivity in Germany. Discussion paper No. 02-50. Mannheim: Centre for European Economic Research/ZEW.

ZWICK, T. (2003). Works councils and the productivity impact of direct employee participation. Discussion Paper No. 03-47. Mannheim: Centre for European EconomicResearch/ZEW. 
Table 1

Selected U.S. studies examining the effect of employee involvement/high performance work practices on firm performance

\begin{tabular}{|c|c|c|c|c|c|}
\hline Study & Data & Methodology & EI/HWPA measure & Union variable & Findings \\
\hline $\begin{array}{l}\text { 1. Huselid } \\
\text { and Becker } \\
(1997)^{\mathrm{a}}\end{array}$ & $\begin{array}{l}1991 \text { sample of } \\
820 \text { publicly- } \\
\text { quoted companies } \\
\text { with more than } 100 \\
\text { employees; and a } \\
\text { panel of } 218 \\
\text { companies, } 1991- \\
93 \text {, also used in } \\
\text { cross section for } \\
1991 \text { and } 1993 .\end{array}$ & $\begin{array}{l}\text { Cross section, fixed } \\
\text { effects, and random effects } \\
\text { models. Dependent } \\
\text { variable: financial } \\
\text { performance, measured by } \\
\text { Tobin's q and the gross } \\
\text { rate of return on assets. }\end{array}$ & $\begin{array}{l}13 \text { high performance work } \\
\text { practices. Factor analysis } \\
\text { used to identify } 2 \text { factors or } \\
\text { groupings, and scales } \\
\text { constructed for each factor } \\
\text { by averaging those } \\
\text { questions loading clearly } \\
\text { on each respective factor. } \\
\text { However, since the effects } \\
\text { of a change in the human } \\
\text { resource system was found } \\
\text { to be the same whether it } \\
\text { occurred through a unit } \\
\text { change in either factor, the } \\
\text { authors subsequently sum } \\
\text { the two dimensions. }\end{array}$ & $\begin{array}{l}\text { Union coverage included } \\
\text { in the control set, but its } \\
\text { effect not separately } \\
\text { identified. }\end{array}$ & $\begin{array}{l}\text { Strong effects of human resource } \\
\text { strategy (factors and summed } \\
\text { factors) on financial performance } \\
\text { reported in cross section. } \\
\text { Specifically, a one standard } \\
\text { deviation increase in the firm's } \\
\text { usage of high performance work } \\
\text { systems increased Tobin's q by } \\
14 \% \text { and the accounting rate of } \\
\text { return by between } 13 \text { and } 28 \% \text {. } \\
\text { In the fixed effects specifications, } \\
\text { however, the effects were only } \\
\text { one-fourth as large and were } \\
\text { statistically insignificant } \\
\text { throughout. However, correction } \\
\text { for measurement error in the } \\
\text { panel is claimed to yield impact } \\
\text { effects that are in line with the } \\
\text { cross-section estimates. }\end{array}$ \\
\hline $\begin{array}{l}2 . \\
\text { Ichniowski, } \\
\text { Shaw, and } \\
\text { Prennushi } \\
(1997)^{b}\end{array}$ & $\begin{array}{l}36 \text { production lines } \\
\text { of } 17 \text { steel } \\
\text { producers. Up to } \\
2,190 \text { monthly } \\
\text { observations in the } \\
\text { panel. }\end{array}$ & $\begin{array}{l}\text { OLS and fixed effects } \\
\text { engineering production } \\
\text { functions. Dependent } \\
\text { variable: production } \\
\text { uptime, namely, the } \\
\text { fraction of scheduled } \\
\text { operating time that the line } \\
\text { actually runs. }\end{array}$ & $\begin{array}{l}\text { Up to } 15 \text { individual human } \\
\text { resource management } \\
\text { variables are identified. } \\
\text { Grouped into } 4 \text { HRM } \\
\text { 'systems' from HRM1 } \\
\text { ('traditional') where none } \\
\text { of (11) practices were } \\
\text { encountered to HRM4 } \\
\text { ('innovative') where all } \\
\text { practices are found. } \\
\text { Identification of grouping } \\
\text { is on the basis of } \\
\text { inspection, but also }\end{array}$ & $\begin{array}{l}\text { Meetings with unions and } \\
\text { union status of the } \\
\text { production line. }\end{array}$ & $\begin{array}{l}\text { OLS results show that uptime } \\
\text { increases monotonically in } \\
\text { degree of HRM innovation. Fixed } \\
\text { effect estimates - based on HRM } \\
\text { group changers - also indicates } \\
\text { this positive hierarchical pattern. } \\
\text { Estimated productivity effects } \\
\text { very similar across specifications. } \\
\text { No real indication that individual } \\
\text { HRM practices or unionism have } \\
\text { an additional (to HRM group) } \\
\text { effect on the production measure } \\
\text { in either OLS or fixed effect }\end{array}$ \\
\hline
\end{tabular}




\begin{tabular}{|c|c|c|c|c|c|}
\hline & & & $\begin{array}{l}\text { supported by/robust to } \\
\text { statistical classification } \\
\text { procedures. Models } \\
\text { include up to } 25 \text { controls } \\
\text { for detailed features of the } \\
\text { line (e.g. line width and } \\
\text { speed). }\end{array}$ & & $\begin{array}{l}\text { specifications. In short. } \\
\text { innovative employment practices } \\
\text { are complements. }\end{array}$ \\
\hline $\begin{array}{l}\text { 3. Cappelli, } \\
\text { and } \\
\text { Neumark } \\
\text { (2001) }\end{array}$ & $\begin{array}{l}\text { National Employer } \\
\text { Surveys of } 1994 \\
\text { and } 1997 \text { matched } \\
\text { to the } 1977 \\
\text { Longitudinal } \\
\text { Research Database } \\
\text { (LRD) to provide } \\
\text { panels for } 1977-93 \\
\text { and } 1977-96 . \\
\text { Number of } \\
\text { observations is } 443 \\
\text { and } 666 \\
\text { respectively. It is } \\
\text { assumed that } \\
\text { EI/HPWP } \\
\text { measures were } \\
\text { only introduced } \\
\text { some time after } \\
1977 \text { so that their } \\
\text { 'levels' observed } \\
\text { in } 1993 \text { and } 1996 \\
\text { can be used in first } \\
\text { difference } \\
\text { estimates. }\end{array}$ & $\begin{array}{l}\text { OLS regressions for } 1993 \\
\text { and } 1996 \text { cross sections } \\
\text { and for models in first } \\
\text { differences. Dependent } \\
\text { variables: log sales per } \\
\text { worker; log labour costs } \\
\text { per worker; log of the } \\
\text { inverse of unit labour } \\
\text { costs. }\end{array}$ & $\begin{array}{l}11 \text { work practices } \\
\text { including benchmarking } \\
\text { and computer usage in } \\
\text { addition to 'employee } \\
\text { involvement mechanisms' } \\
\text { (team working and TQM) } \\
\text { and supportive measures } \\
\text { (job rotation, gain-sharing, } \\
\text { etc.) These considered } \\
\text { singly and severally in } 6 \\
\text { bundles suggested by a } \\
\text { priori reasoning. }\end{array}$ & $\begin{array}{l}\text { No union argument is } \\
\text { included in the control } \\
\text { variables. }\end{array}$ & $\begin{array}{l}\text { The results for productivity } \\
\text { indicate a positive association } \\
\text { between individual practices and } \\
\text { log sales per worker. But } \\
\text { statistical significance is weak } \\
\text { and the effect is further } \\
\text { attenuated in first difference } \\
\text { estimates. Some evidence of } \\
\text { potential synergies in the bundles } \\
\text { but the balance of the main and } \\
\text { interactive effects is seldom } \\
\text { statistically significant. The } \\
\text { results for labour costs suggest } \\
\text { that several practices increase } \\
\text { costs in roughly similar amounts } \\
\text { to the productivity effects. No } \\
\text { indications of any efficiency } \\
\text { effects (i.e. reductions in unit } \\
\text { costs). }\end{array}$ \\
\hline $\begin{array}{l}\text { 4. Cooke } \\
(1994)^{c}\end{array}$ & $\begin{array}{l}\text { 841manufacturing } \\
\text { firms in Michigan, } \\
1989 .\end{array}$ & $\begin{array}{l}\text { OLS cross section } \\
\text { estimates. Dependent } \\
\text { variable: company } \\
\text { performance, defined as } \\
\text { value added net of labour } \\
\text { cost per employee. Three } \\
\end{array}$ & $\begin{array}{l}\text { Employee participation, as } \\
\text { proxied by presence of } \\
\text { work teams, and group- } \\
\text { based incentives, as } \\
\text { measured by existence of } \\
\text { profit/gain sharing plans. } \\
\end{array}$ & $\begin{array}{l}\text { Union status of the firm is } \\
\text { interacted with team and } \\
\text { profit/gain sharing } \\
\text { variables. Reference } \\
\text { category: nonunion firms } \\
\text { with neither team working }\end{array}$ & $\begin{array}{l}\text { Union firms are } 13 \% \text { more } \\
\text { efficient than nonunion firms. If } \\
\text { union firms have teams they are } \\
35 \% \text { more efficient than the } \\
\text { nonunion no-team counterfactual. } \\
\text { The corresponding advantage of }\end{array}$ \\
\hline
\end{tabular}




\begin{tabular}{|c|c|c|c|c|c|}
\hline & & $\begin{array}{l}\text { separate regressions for } \\
\text { value-added per employee, } \\
\text { average hourly wages, and } \\
\text { labour costs as a share of } \\
\text { labour cost. Firm } \\
\text { performance is thus the } \\
\text { estimated value added per } \\
\text { employee for the relevant } \\
\text { EI/HPWP combination less } \\
\text { the estimated wage } \\
\text { difference adjusted for the } \\
\text { labour cost share } \\
\text { differential. }\end{array}$ & & nor profit/gain sharing. & $\begin{array}{l}\text { nonunion firms with team } \\
\text { working is actually negative. But } \\
\text { the addition of profit/gain sharing } \\
\text { has a much bigger relative payoff } \\
\text { in nonunion than union firms } \\
\text { (18\% versus } 6.5 \%) \text {. The } \\
\text { interaction of teams and } \\
\text { profit/gain sharing is modest in } \\
\text { nonunion firms and negative in } \\
\text { union firms. No significance } \\
\text { levels of these effects are } \\
\text { provided. }\end{array}$ \\
\hline $\begin{array}{l}\text { 5. Black and } \\
\text { Lynch } \\
(2001)\end{array}$ & $\begin{array}{l}\text { Educational } \\
\text { Quality of the } \\
\text { Workforce } \\
\text { National } \\
\text { Employers Survey } \\
\text { (EQW-NES) data } \\
\text { for } 1994 \text { matched } \\
\text { to information } \\
\text { from the LRD for } \\
\text { 1987-93 (n=638). }\end{array}$ & $\begin{array}{l}\text { Cobb-Douglas production } \\
\text { function. Dependent } \\
\text { variable: log sales per } \\
\text { employee. Cross -section } \\
\text { estimates for } 1994 \text { plus } \\
\text { panel analysis for 1987-93 } \\
\text { period. The panel analysis } \\
\text { uses within and GMM } \\
\text { estimators to first derive } \\
\text { average residuals for each } \\
\text { establishment. These } \\
\text { residuals are then regressed } \\
\text { on the EI/HPWP measures } \\
\text { and other time-invariant } \\
\text { variables from the 1994 } \\
\text { EQW-NES (technology, } \\
\text { worker characteristics, } \\
\text { etc.) }\end{array}$ & $\begin{array}{l}6 \text { variables proxying } \\
\text { HPWP (TQM, } \\
\text { benchmarking, number of } \\
\text { managerial levels, number } \\
\text { of employees per } \\
\text { supervisor, proportion of } \\
\text { workers in self-managed } \\
\text { teams, and log number of } \\
\text { workers in training); } 2 \\
\text { measures of 'employee } \\
\text { voice’ (unionization, and } \\
\text { proportion of worker } \\
\text { meeting regularly in } \\
\text { groups); and } 2 \text { types of } \\
\text { profit sharing (for } \\
\text { management and for } \\
\text { production workers). }\end{array}$ & $\begin{array}{l}\text { Union presence plus } \\
\text { interactions with } \\
\text { nonmanagerial profit } \\
\text { sharing and TQM. }\end{array}$ & $\begin{array}{l}\text { In the cross sections only one } \\
\text { HPWP - benchmarking - is } \\
\text { statistically significant. No } \\
\text { synergies between the HPWPs } \\
\text { are detected. Of the other } \\
\text { variables, the proportion of } \\
\text { workers meeting in groups and } \\
\text { profit sharing schemes for } \\
\text { production workers often seem to } \\
\text { raise productivity. Of the } \\
\text { interactions tested, there is a } \\
\text { positive association between } \\
\text { unionism and profit sharing for } \\
\text { production workers. The panel } \\
\text { estimators produce basically } \\
\text { similar results except that TQM } \\
\text { now enters negatively as does the } \\
\text { union variable. The latter effect is } \\
\text { offset by the union-profit sharing } \\
\text { interaction. }\end{array}$ \\
\hline $\begin{array}{l}\text { 6. Black and } \\
\text { Lynch } \\
(2002)\end{array}$ & $\begin{array}{l}\text { EQW-NES data } \\
\text { for } 1994 \text { and } 1997 . \\
\text { Cross-section } \\
\text { sample is } 1,443\end{array}$ & $\begin{array}{l}\text { Cobb-Douglas production } \\
\text { function estimates in cross } \\
\text { section (1996) and first } \\
\text { differences (1993-96). }\end{array}$ & $\begin{array}{l}\text { Somewhat different mix to } \\
\text { Black and Lynch (2001) in } \\
\text { row 5. In addition to the } \\
\text { proportion of workers in }\end{array}$ & $\begin{array}{l}\text { Union presence plus } \\
\text { interactions of the union } \\
\text { measure with profit } \\
\text { sharing, re-engineering, }\end{array}$ & $\begin{array}{l}\text { For the } 1996 \text { cross section, of the } \\
\text { HPWP measures only the } \\
\text { positive effect of profit sharing } \\
\text { on productivity is well }\end{array}$ \\
\hline
\end{tabular}




\begin{tabular}{|l|l|l|l|l|}
\hline $\begin{array}{l}\text { firms; panel } \\
\text { sample comprises } \\
\text { 284 firms. }\end{array}$ & $\begin{array}{l}\text { Dependent variable: log } \\
\text { sales per worker. Parallel } \\
\text { wage functions are also } \\
\text { estimated for 1996 and } \\
1993-96 .\end{array}$ & $\begin{array}{l}\text { self- managed teams, } \\
\text { benchmarking, and the } \\
\text { number of managerial } \\
\text { levels, the HPWP set also } \\
\text { includes 're-engineering' } \\
\text { and profit sharing. } \\
\text { Employee voice variables } \\
\text { are as before, namely, } \\
\text { union presence and the } \\
\text { proportion of workers } \\
\text { meeting regularly in } \\
\text { groups. }\end{array}$ & $\begin{array}{l}\text { and the percentage of } \\
\text { workers meeting regularly } \\
\text { in groups. }\end{array}$ & $\begin{array}{l}\text { determined across specifications. } \\
\text { The union role, but not the other } \\
\text { voice argument is positive and } \\
\text { statistically significant. But the } \\
\text { union profit sharing interaction } \\
\text { term is larger and of opposite } \\
\text { sign. The union re-engineering } \\
\text { interaction term is positive and } \\
\text { well determined. For the panel } \\
\text { estimates, the effect of re- } \\
\text { engineering (proportions of } \\
\text { workers in self-managed teams) } \\
\text { is positive (negative) and well } \\
\text { determined. Neither voice } \\
\text { argument is statistically } \\
\text { significant. No interaction team is } \\
\text { statistically significant other than } \\
\text { that between union presence and } \\
\text { the proportion of workers } \\
\text { meeting regularly in groups, } \\
\text { which is strongly positive. For } \\
\text { their part, the wage regressions } \\
\text { show further variation. }\end{array}$ \\
& & &
\end{tabular}

Notes:

a See also Huselid (1995).

b See also Ichniowski (1990).

c See also Cooke (1992). 
Table 2

Recent estimates of the effects of works councils on performance.

\begin{tabular}{|c|c|c|c|c|c|}
\hline Study & Data & Dependent Variable & Methodology & $\begin{array}{l}\text { Works council } \\
\text { measure/controls }\end{array}$ & Findings \\
\hline $\begin{array}{l}\text { 1. Addison, } \\
\text { Schnabel, and } \\
\text { Wagner } \\
\text { (2001) }\end{array}$ & $\begin{array}{l}\text { Hannover Firm } \\
\text { Panel. 900 } \\
\text { establishments } \\
\text { from the } 1994 \\
\text { wave. }\end{array}$ & $\begin{array}{l}\text { Value added per worker; } \\
\text { subjective measures of } \\
\text { financial performance; } \\
\text { wages and salaries per } \\
\text { employee (and the } \\
\text { percentage 'wage gap'); } \\
\text { three labour turnover } \\
\text { measures (hires, separations } \\
\text { and gross turnover); and two } \\
\text { innovation measures } \\
\text { (introduction of new } \\
\text { processes/products). }\end{array}$ & $\begin{array}{l}\text { Single equation estimates. } \\
\text { Separate results for all - } \\
\text { establishment sample and } \\
\text { subset of plants with 21-100 } \\
\text { employees. }\end{array}$ & $\begin{array}{l}\text { Works council presence. Controls } \\
\text { include establishment size/age; } \\
\text { measures of workforce composition } \\
\text { and skill; product market } \\
\text { competition; capacity utilization; } \\
\text { profit sharing; state of technology; } \\
\text { 'excessive' wage costs; and } \\
\text { industry dummies. }\end{array}$ & $\begin{array}{l}\text { Works council presence is } \\
\text { associated with higher productivity } \\
\text { overall but not for plants with 21- } \\
100 \text { employees. Profitability } \\
\text { systematically lower in works } \\
\text { council regimes. Wages higher in } \\
\text { the presence of works councils, but } \\
\text { sources of these higher earnings are } \\
\text { not transparent. All labour turnover } \\
\text { measures are reduced in works } \\
\text { council settings, other than for the } \\
\text { subset of smaller establishments. } \\
\text { Innovation measure unaffected by } \\
\text { works control presence. }\end{array}$ \\
\hline $\begin{array}{l}\text { 2. Hübler and } \\
\text { Jirjahn (2003) }\end{array}$ & $\begin{array}{l}\text { Hannover Firm } \\
\text { Panel. Pooled } \\
\text { data from the } \\
1994 \text { and } 1996 \\
\text { waves. }\end{array}$ & $\begin{array}{l}\text { Value-added per employee } \\
\text { and wages and salaries per } \\
\text { employee. }\end{array}$ & $\begin{array}{l}\text { Bivariate probit maximum } \\
\text { likelihood estimates of works } \\
\text { council presence and } \\
\text { coverage by collective } \\
\text { agreement to form selection } \\
\text { arguments in wage and } \\
\text { productivity equations. }\end{array}$ & $\begin{array}{l}\text { Works council presence and } \\
\text { coverage by a collective agreement. } \\
\text { Controls include establishment } \\
\text { age/size/legal status; product } \\
\text { market competition; measures of } \\
\text { workforce composition and skill; } \\
\text { profit sharing; state of technology; } \\
\text { team work; and industry dummies. }\end{array}$ & $\begin{array}{l}\text { In separate productivity regressions } \\
\text { by collective bargaining status, the } \\
\text { positive effect of works councils on } \\
\text { performance is statistically } \\
\text { significant only where the plant is } \\
\text { covered by a collective agreement. } \\
\text { Wages are higher under both } \\
\text { collective bargaining regimes, } \\
\text { although the effect is better } \\
\text { determined where there is no } \\
\text { collective agreement. }\end{array}$ \\
\hline
\end{tabular}




\begin{tabular}{|c|c|c|c|c|c|}
\hline $\begin{array}{l}\text { 3. Frick and } \\
\text { Möller (2003) }\end{array}$ & $\begin{array}{l}\text { IAB } \\
\text { Establishment } \\
\text { Panel. Cross } \\
\text { sections for } \\
1998 \text { and } 2000 .\end{array}$ & Log value added. & $\begin{array}{l}\text { OLS estimation of Cobb- } \\
\text { Douglas, CES, and translog } \\
\text { production functions. } \\
\text { Separate estimates for West } \\
\text { and East Germany; summary } \\
\text { results for manufacturing and } \\
\text { services. }\end{array}$ & $\begin{array}{l}\text { Works council presence. In addition } \\
\text { to log capital (proxied by } \\
\text { replacement investment)and log } \\
\text { employment, the regressors } \\
\text { comprise: profit sharing for } \\
\text { employees; process innovation; } \\
\text { product innovation; employment of } \\
\text { apprentices; coverage by a } \\
\text { collective agreement; percentage of } \\
\text { qualified employees; percentage of } \\
\text { sales exported; and } 14 \text { sector } \\
\text { dummies. }\end{array}$ & $\begin{array}{l}\text { Plants with works councils have } \\
\text { sharply higher productivity of } 25 \% \\
(30 \%) \text { in West (East) Germany. } \\
\text { Disaggregation by sector confirms } \\
\text { results other than for West German } \\
\text { manufacturing in both } 1998 \text { and } \\
\text { 2000. Works council interaction } \\
\text { with profit-sharing is statistically } \\
\text { insignificant. }\end{array}$ \\
\hline $\begin{array}{l}\text { 4. Schank, } \\
\text { Schnabel, and } \\
\text { Wagner } \\
\text { (2004) }\end{array}$ & $\begin{array}{l}\text { IAB } \\
\text { Establishment } \\
\text { Panel, 1993- } \\
2000 . \\
\text { Unbalanced and } \\
\text { balanced panels } \\
\text { of plants with } \\
21-100 \\
\text { employees. }\end{array}$ & Log sales & $\begin{array}{l}\text { Fixed effects stochastic } \\
\text { frontier production function } \\
\text { estimated separately for } \\
\text { plants with and without works } \\
\text { councils and for balanced and } \\
\text { unbalanced panels. The } \\
\text { comparison is between the } \\
\text { technical efficiency estimates } \\
\text { - and the 95\% confidence } \\
\text { intervals - of the median } \\
\text { works council plant and its } \\
\text { non-works council } \\
\text { counterpart. }\end{array}$ & $\begin{array}{l}\text { Works council presence. Regressors } \\
\text { include log employment; shares of } \\
\text { part-time, skilled, and female } \\
\text { employees; } 41 \text { sector dummies; and } \\
7 \text { year dummies. }\end{array}$ & $\begin{array}{l}\text { There are no statistically significant } \\
\text { differences in efficiency between } \\
\text { establishments with and without } \\
\text { works councils. Results robust to } \\
\text { disaggregation by broad sector and } \\
\text { to time interval (use of two } \\
\text { different five-year balanced panels). }\end{array}$ \\
\hline $\begin{array}{l}\text { 5. Addison, } \\
\text { Bellmann, } \\
\text { Schnabel, and } \\
\text { Wagner } \\
\text { (2004) }\end{array}$ & $\begin{array}{l}\text { IAB } \\
\text { Establishment } \\
\text { Panel. Initial } \\
\text { sample of 1,544 } \\
\text { establishments } \\
\text { all without } \\
\text { works councils } \\
\text { in } 1996 \text {. }\end{array}$ & $\begin{array}{l}\text { Changes in quits, sales per } \\
\text { employee, employment, and } \\
\text { the profit-situation. }\end{array}$ & $\begin{array}{l}\text { Nonparametric propensity } \\
\text { score matching model. } \\
\text { ‘Treated' group comprises all } \\
\text { plants in which a works } \\
\text { council was set up between } \\
1996 \text { and 1998. Matched } \\
\text { plants derived from 1,513 } \\
\text { controls. }\end{array}$ & Introduction of a works council. & $\begin{array}{l}\text { Mean values for the performance } \\
\text { indicators in establishments that } \\
\text { experienced the formation of a } \\
\text { works council are not statistically } \\
\text { different from those obtaining in } \\
\text { plants that remained free of works } \\
\text { councils. Results are robust to } \\
\text { outliers. }\end{array}$ \\
\hline $\begin{array}{l}\text { 6. Addison, } \\
\text { Bellmann, and } \\
\text { Kölling (2004) }\end{array}$ & $\begin{array}{l}\text { IAB } \\
\text { Establishment } \\
\text { Panel, 1996- } \\
\end{array}$ & Plant closings. & $\begin{array}{l}\text { Probit estimates for the } \\
\text { following samples: all-plants; } \\
\text { plants stratified by whether or }\end{array}$ & $\begin{array}{l}\text { Works council presence. Apart } \\
\text { from coverage by a collective } \\
\text { agreement and establishment size, }\end{array}$ & $\begin{array}{l}\text { For the aggregate sample, works } \\
\text { councils associated with } \\
\text { significantly higher closings. Works }\end{array}$ \\
\hline
\end{tabular}




\begin{tabular}{|l|l|l|l|l|}
\hline & 2000. & $\begin{array}{l}\text { not they are covered by a } \\
\text { collective agreement; plants } \\
\text { stratified by size (less than or } \\
\text { more that 50 employees); and } \\
\text { plants stratified by both } \\
\text { collective agreement and size. }\end{array}$ & $\begin{array}{l}\text { the covariates include plant age; } \\
\text { workforce composition and skills; } \\
\text { recent layoff experience; state of } \\
\text { technology; regional unemployment } \\
\text { rate; and industry dummies. }\end{array}$ & $\begin{array}{l}\text { council effect is sharper for the } \\
\text { uncovered sector and for smaller } \\
\text { plants but the difference is not } \\
\text { statistically significant. Only for } \\
\text { small plants that are covered by a } \\
\text { collective agreement is there any } \\
\text { suggestion that collective } \\
\text { bargaining coverage can lower } \\
\text { closure rate. }\end{array}$ \\
& & & \\
& & &
\end{tabular}


Table 3

Works council coefficient estimates from a translog production function fitted to IAB establishment panel data, 1997-2000

\begin{tabular}{|c|c|c|c|}
\hline Sample & All & $\begin{array}{c}\text { Sector } \\
\text { Manufacturing }\end{array}$ & Services \\
\hline \multicolumn{4}{|c|}{$\begin{array}{l}\text { Firms with 21-100 } \\
\text { employees }\end{array}$} \\
\hline Pooled & $\begin{array}{l}0.118^{* * *} \\
(3.22)\end{array}$ & $\begin{array}{r}0.046 \\
(1.03)\end{array}$ & $\begin{array}{l}0.183^{* * *} \\
(3.05)\end{array}$ \\
\hline 1997 & $\begin{array}{l}0.123^{*} \\
(1.86)\end{array}$ & $\begin{array}{l}\text { 0.119* } \\
(1.73)\end{array}$ & $\begin{array}{c}0.098 \\
(0.82)\end{array}$ \\
\hline 1998 & $\begin{array}{l}0.107^{*} \\
(1.94)\end{array}$ & $\begin{array}{c}0.063 \\
(0.94)\end{array}$ & $\begin{array}{c}0.145 \\
(0.61)\end{array}$ \\
\hline 1999 & $\begin{array}{c}0.056 \\
(1.16)\end{array}$ & $\begin{array}{l}-0.011 \\
(0.18)\end{array}$ & $\begin{array}{l}0.139 * \\
(1.72)\end{array}$ \\
\hline 2000 & $\begin{array}{l}0.172 * * * \\
(3.60)\end{array}$ & $\begin{array}{r}0.070 \\
(1.22)\end{array}$ & $\begin{array}{l}0.269 * * * \\
(3.41)\end{array}$ \\
\hline \multicolumn{4}{|c|}{$\begin{array}{l}\text { Firms with } \geq 5 \\
\text { employees }\end{array}$} \\
\hline Pooled & $\begin{array}{l}0.232 * * \\
(\mathbf{8 . 8 8 )}\end{array}$ & $\begin{array}{l}0.177^{* * *} \\
(5.71)\end{array}$ & $\begin{array}{l}0.275^{* * *} \\
(3.05)\end{array}$ \\
\hline
\end{tabular}

Notes: The dependent variable is log total sales. In addition to the log capital stock, log number of employees, and works council presence, the regressors are: investment in ICT, state of technology, workforce composition (share of part timers, apprentices, and skilled workers), coverage by a collective agreement, a dummy for eastern Germany and, for the relevant pooled/cross section regressions, sector and/or year dummies.

$|t|$ - values in parentheses

$* * *, *$ denote significance at the .01 and .10 levels, respectively.

Source: Addison, Schank, Schnabel, and Wagner (2003). 
Table 4

Selected German studies examining the effect of innovative work practices and works councils on performance

\begin{tabular}{|c|c|c|c|c|c|}
\hline Study & Data & Methodology & EI/HPWP measure & $\begin{array}{c}\text { Works council } \\
\text { variable }\end{array}$ & Findings \\
\hline $\begin{array}{l}\text { 1. Frick } \\
\text { (2002 }\end{array}$ & $\begin{array}{l}1,700 \\
\text { establishments } \\
\text { from the sixth } \\
\text { wave of the } \\
\text { NIFA-Panel. } \\
\text { Dataset } \\
\text { identifies five } \\
\text { types of HPWP, } \\
\text { as well as five } \\
\text { types of works } \\
\text { council and a } \\
\text { measure of } \\
\text { works council } \\
\text { involvement. }\end{array}$ & $\begin{array}{l}\text { Descriptive analysis of } \\
\text { HPWPs by works council } \\
\text { presence, involvement, and } \\
\text { type. Multiple classification } \\
\text { analysis for same categories } \\
\text { as in descriptive treatment } \\
\text { and five covariates (number } \\
\text { of employees, sales per- } \\
\text { employee, stock of orders, } \\
\text { and capacity/manpower } \\
\text { utilization). }\end{array}$ & $\begin{array}{l}\text { The five measures are: } \\
\text { reduction in hierarchies; } \\
\text { delegation of decision } \\
\text { making; work groups } \\
\text { with independent } \\
\text { budgets; group or team } \\
\text { work; flexible working } \\
\text { time. }\end{array}$ & $\begin{array}{l}\text { Five works council } \\
\text { types range from } \\
\text { 'antagonistic' to } \\
\text { 'excluded.' The } \\
\text { measure of works } \\
\text { council involvement } \\
\text { signifies greater } \\
\text { engagement of } \\
\text { works council in } \\
\text { processes of } \\
\text { technological or } \\
\text { organizational } \\
\text { change than laid } \\
\text { down under law or } \\
\text { by collective } \\
\text { agreements. }\end{array}$ & $\begin{array}{l}\text { Plants with works councils use more } \\
\text { HPWPs than do plants without works } \\
\text { councils, but difference is not statistically } \\
\text { significant. Plants with more involved } \\
\text { works councils have more HPWPs than } \\
\text { their less involved counterparts. But the } \\
\text { number of HPWPs is highest in } \\
\text { circumstances where works council is } \\
\text { rated 'antagonistic.' HPWPs are reported } \\
\text { to have a positive effect on establishment } \\
\text { performance but a negative effect on } \\
\text { labour demand.' }\end{array}$ \\
\hline $\begin{array}{l}\text { 2. FitzRoy } \\
\text { and Kraft } \\
\text { (1995) }\end{array}$ & $\begin{array}{l}\text { Pooled data for } \\
1977 \text { and } 1979 \\
\text { for } 65 \text { metal } \\
\text { working firms } \\
\text { in West } \\
\text { Germany. }\end{array}$ & $\begin{array}{l}\text { Value added production } \\
\text { function estimated } \\
\text { separately for profit-sharing } \\
\text { firms and non profit-sharing } \\
\text { firms, with correction for } \\
\text { selection into profit sharing } \\
\text { status. Also estimation of } \\
\text { full interaction equation for } \\
\text { the whole sample. }\end{array}$ & $\begin{array}{l}\text { Profit sharing for the } \\
\text { workforce. }\end{array}$ & $\begin{array}{l}\text { Presence of works } \\
\text { council. }\end{array}$ & $\begin{array}{l}\text { The effect of works councils on } \\
\text { productivity measure is negative and } \\
\text { statistically significant in non-sharing } \\
\text { firms but is positive and statistically } \\
\text { significant in profit-sharing firms. } \\
\text { Interaction effect between works councils } \\
\text { and profit-sharing in full interaction } \\
\text { equation is statistically insignificant. }\end{array}$ \\
\hline $\begin{array}{l}\text { 3. Jirjahn } \\
\text { (2003) }\end{array}$ & $\begin{array}{l}\text { Pooled data } \\
\text { from the } 1994 \\
\text { and } 1996 \text { waves } \\
\text { of the Hannover } \\
\text { Firm Panel. }\end{array}$ & $\begin{array}{l}\text { Single-equation OLS pooled } \\
\text { productivity estimates. } \\
\text { Dependent variable: value } \\
\text { added per employee. } \\
\text { Auxiliary probit model of } \\
\text { works council presence }\end{array}$ & $\begin{array}{l}\text { Managerial profit } \\
\text { sharing. Some } \\
\text { innovative practices are } \\
\text { also included in the } \\
\text { probit equation (e.g. } \\
\text { further training and }\end{array}$ & $\begin{array}{l}\text { Works council } \\
\text { presence. }\end{array}$ & $\begin{array}{l}\text { Executive profit sharing schemes are } \\
\text { productive for both samples. The } \\
\text { interaction between executive profit } \\
\text { sharing schemes and works council } \\
\text { presence is negative and statistically } \\
\text { significant for the all-establishment }\end{array}$ \\
\hline
\end{tabular}




\begin{tabular}{|c|c|c|c|c|c|}
\hline & & $\begin{array}{l}\text { provided but not used to } \\
\text { instrument works council } \\
\text { presence. Separate estimates } \\
\text { for all plants and subset of } \\
\text { plants with } 21-100 \\
\text { employees. }\end{array}$ & $\begin{array}{l}\text { flexible working hours) } \\
\text { but not in the } \\
\text { productivity equation. }\end{array}$ & & $\begin{array}{l}\text { sample. Works council effect is positive } \\
\text { and statistically significant throughout. }\end{array}$ \\
\hline $\begin{array}{l}\text { 4. Wolf and } \\
\text { Zwick (2002) }\end{array}$ & $\begin{array}{l}\text { IAB } \\
\text { Establishment } \\
\text { Panel, for a } \\
1999 \text { cross } \\
\text { section and a } \\
1996-99 \text { panel. }\end{array}$ & $\begin{array}{l}\text { Cobb-Douglas production } \\
\text { function with capital } \\
\text { approximated by } \\
\text { replacement investments. } \\
\text { Dependent variable: value } \\
\text { added and average value } \\
\text { added. Cross-section } \\
\text { estimates with and without } \\
\text { correction for endogeniety } \\
\text { of HPWP. For the panel, the } \\
\text { estimation follows the } \\
\text { Black-Lynch (2001) two- } \\
\text { step procedure (see Table } 1 \text {, } \\
\text { row entry 5), with the } \\
\text { second stage also } \\
\text { controlling for the } \\
\text { endogeneity of HPWPs. }\end{array}$ & $\begin{array}{l}\text { Six HPWPs: shifting of } \\
\text { responsibilities to lower } \\
\text { level in hierarchy; team } \\
\text { work; work groups with } \\
\text { independent budgets; } \\
\text { employee share } \\
\text { ownership; profit } \\
\text { sharing; training to } \\
\text { support organizational } \\
\text { change; and incentive } \\
\text { training. These HPWPs } \\
\text { are aggregated into two } \\
\text { independent factors } \\
\text { ('organizational } \\
\text { change' and } \\
\text { 'incentives') using } \\
\text { principal components } \\
\text { factor analysis. }\end{array}$ & $\begin{array}{l}\text { Works council } \\
\text { presence }\end{array}$ & $\begin{array}{l}\text { In cross section, the positive effect of } \\
\text { 'incentives' (share ownership, profit } \\
\text { sharing, supportive training, and incentive } \\
\text { training) results from their being } \\
\text { introduced by firms when they are } \\
\text { prospering. In the panel (second- step) } \\
\text { estimates and after correcting for selection, } \\
\text { 'organizational changes' (shifting } \\
\text { responsibilities, team work, and } \\
\text { independent work groups) have } \\
\text { significantly positive effect on productivity } \\
\text { and are also introduced to deal with } \\
\text { structural problems - structural } \\
\text { productivity gaps. No interaction between } \\
\text { 'incentives' and 'organizational changes.' } \\
\text { Separate works council effect not robust in } \\
\text { cross section, but in panel estimates work } \\
\text { council presence has significantly positive } \\
\text { impact on the establishment-specific fixed } \\
\text { effect. }\end{array}$ \\
\hline $\begin{array}{l}\text { 5. Zwick } \\
\text { (2003) }\end{array}$ & $\begin{array}{l}\text { IAB } \\
\text { Establishment } \\
\text { Panel, 1997- } \\
2000 .\end{array}$ & $\begin{array}{l}\text { Cobb-Douglas production } \\
\text { analysis function. } \\
\text { Dependent variable: value- } \\
\text { added and average value- } \\
\text { added. In other words, the } \\
\text { same two-step procedure } \\
\text { used by Wolf and Zwick } \\
\text { (2002) but with GMM } \\
\text { (GMM-SYS) estimator } \\
\text { rather than within estimator } \\
\text { alone to estimate the }\end{array}$ & $\begin{array}{l}\text { 'Participative work } \\
\text { forms' based on } \\
\text { delegation of } \\
\text { responsibility and } \\
\text { decision making to } \\
\text { lower-levels in the } \\
\text { hierarchy, team work, } \\
\text { and work groups with } \\
\text { independent budgets. } \\
\text { These three measures } \\
\text { are aggregated to form }\end{array}$ & $\begin{array}{l}\text { Works council } \\
\text { presence, and } \\
\text { estimated works } \\
\text { council presence in a } \\
\text { switching regression } \\
\text { model. }\end{array}$ & $\begin{array}{l}\text { After accounting for the endogeneity of } \\
\text { participative work forms, the productivity } \\
\text { effect of such practices is around } 25 \\
\text { percent. In the switching regression, (the } \\
\text { instrumented value for) participation is } \\
\text { only (marginally) statistically significant in } \\
\text { the sample of works council firms. } \\
\text { Selection into works council status is well } \\
\text { determined in both equations. }\end{array}$ \\
\hline
\end{tabular}




\begin{tabular}{|c|c|c|c|c|c|}
\hline & & $\begin{array}{l}\text { production function and the } \\
\text { time-invariant establishment } \\
\text { fixed effect. }\end{array}$ & $\begin{array}{l}\text { a single participation } \\
\text { variable set equal to one } \\
\text { if at least one of the } \\
\text { three measures had } \\
\text { been introduced by } \\
\text { 1997. Participation is } \\
\text { endogenized using } \\
\text { instrumental variable } \\
\text { regressions. }\end{array}$ & & \\
\hline $\begin{array}{l}\text { 6. Zwick } \\
\text { (2002) }\end{array}$ & $\begin{array}{l}\text { IAB } \\
\text { Establishment } \\
\text { Panel. Cross } \\
\text { sections for } \\
1998 \text { and } 1999 \\
\text { and panel data } \\
\text { for 1997-99. }\end{array}$ & $\begin{array}{l}\text { Cobb-Douglas production } \\
\text { function approach. } \\
\text { Dependent variable: value } \\
\text { added. Cross section } \\
\text { estimates of effect of } \\
\text { continuous training in } 1997 \\
\text { on labour productivity } \\
\text { levels in } 1998 \text { and } 1999 \text {. } \\
\text { Selection into training status } \\
\text { handled through a probit } \\
\text { regression used to calculate } \\
\text { the probability that a firm } \\
\text { offers training and a Tobit } \\
\text { equation to predict the } \\
\text { intensity of training. }{ }^{b} \text { Fixed } \\
\text { effects panel estimation } \\
\text { using two-step procedure as } \\
\text { in row } 4 \text { and } 5 \text { studies, also } \\
\text { with and without selectivity } \\
\text { correction. }\end{array}$ & $\begin{array}{l}\text { Training incidence (i.e. } \\
\text { presence); training } \\
\text { intensity (number of } \\
\text { trainees divided by } \\
\text { number of employees); } \\
\text { and training type } \\
\text { (formal external } \\
\text { courses, formal internal } \\
\text { courses, training on the } \\
\text { job, seminars and talks, } \\
\text { job rotation, self- } \\
\text { induced learning, and } \\
\text { quality circles). }\end{array}$ & $\begin{array}{l}\text { Works council } \\
\text { presence. }\end{array}$ & $\begin{array}{l}\text { In cross section, (lagged) effects of } \\
\text { training intensity - actual and predicted - } \\
\text { are positively associated with labour } \\
\text { productivity. Formal external training } \\
\text { courses also positive and statistically } \\
\text { significant throughout. Negative effect of } \\
\text { training on-the-job. Selection term is } \\
\text { negative. Panel estimates indicate that } \\
\text { training intensity, formal external and } \\
\text { internal courses, and self-induced learning } \\
\text { have a positive and significant effect on } \\
\text { productivity; after selection is accounted } \\
\text { for, the coefficient estimates for training } \\
\text { intensity and formal training courses } \\
\text { increase in size. Coefficient estimate for } \\
\text { the works council dummy is positive and } \\
\text { statistically significant in cross-section } \\
\text { estimates but not in second-step regression } \\
\text { estimates. }\end{array}$ \\
\hline
\end{tabular}

Notes

a See also Addison and Teixeira (2004).

b See also Gerlach and Jirjahn (2001). 